\title{
Solanum lyratum Extracts Induce Extrinsic and Intrinsic Pathways of Apoptosis in WEHI-3 Murine Leukemia Cells and Inhibit Allograft Tumor
}

\author{
Jai-Sing Yang, ${ }^{1}$ Chia-Chun Wu, ${ }^{2}$ Chao-Lin Kuo, ${ }^{3}$ Yu-Hsuan Lan, ${ }^{4}$ Chin-Chung Yeh, ${ }^{5}$ \\ Chien-Chih Yu, ${ }^{4}$ Jin-Cherng Lien, ${ }^{6}$ Yuan-Man Hsu, ${ }^{2}$ Wei-Wen Kuo, ${ }^{2}$ W. Gibson Wood, \\ Minoru Tsuzuki, ${ }^{8,9}$ and Jing-Gung Chung, 10 \\ ${ }^{1}$ Department of Pharmacology, China Medical University, Taichung 404, Taiwan \\ ${ }^{2}$ Department of Biological Science and Technology, China Medical University, Taichung 404, Taiwan \\ ${ }^{3}$ School of Chinese Pharmaceutical Sciences and Chinese Medicine Resources, China Medical University, Taichung 404, Taiwan \\ ${ }^{4}$ School of Pharmacy, China Medical University, Taichung 404, Taiwan \\ ${ }^{5}$ Department of Urology, China Medical University Hospital, Taichung 404, Taiwan \\ ${ }^{6}$ Graduate Institute of Pharmaceutical Chemistry, China Medical University, Taichung 404, Taiwan \\ ${ }^{7}$ Department of Pharmacology, School of Medicine, Geriatric Research, Education and Clinical Center, VA Medical Center, \\ University of Minnesota, Minneapolis, MN 55455, USA \\ ${ }^{8}$ Department of Biochemistry, Nihon Pharmaceutical University, Saitama 362-0806, Japan \\ ${ }_{9}$ Tsuzuki Institute for Traditional Medicine, China Medical University, Taichung 404, Taiwan \\ ${ }^{10}$ Department of Biotechnology, Asia University, Taichung 413, Taiwan
}

Correspondence should be addressed to Jing-Gung Chung, jgchung@mail.cmu.edu.tw

Received 28 September 2011; Revised 8 January 2012; Accepted 16 February 2012

Academic Editor: Cheppail Ramachandran

Copyright (C) 2012 Jai-Sing Yang et al. This is an open access article distributed under the Creative Commons Attribution License, which permits unrestricted use, distribution, and reproduction in any medium, provided the original work is properly cited.

\begin{abstract}
We investigated the molecular mechanisms of cell cycle arrest and apoptotic death induced by Solanum lyratum extracts (SLE) or diosgenin in WEHI-3 murine leukemia cells in vitro and antitumor activity in vivo. Diosgenin is one of the components of SLE. Our study showed that SLE and diosgenin decreased the viable WEHI-3 cells and induced $\mathrm{G}_{0} / \mathrm{G}_{1}$ phase arrest and apoptosis in concentration- or time-dependent manners. Both reagents increased the levels of ROS production and decreased the mitochondrial membrane potential $\left(\Delta \Psi_{m}\right)$. SLE- and diosgenin-triggered apoptosis is mediated through modulating the extrinsic and intrinsic signaling pathways. Intriguingly, the p53 inhibitor (pifithrin- $\alpha$ ), anti-Fas ligand (FasL) mAb, and specific inhibitors of caspase-8 (z-IETD-fmk), caspase-9 (z-LEHD-fmk), and caspase-3 (z-DEVD-fmk) blocked SLE- and diosgenin-reduced cell viability of WEHI-3 cells. The in vivo study demonstrated that SLE has marked antitumor efficacy against tumors in the WEHI-3 cell allograft model. In conclusion, SLE- and diosgenin-induced $\mathrm{G}_{0} / \mathrm{G}_{1}$ phase arrest and triggered extrinsic and intrinsic apoptotic pathways via p53 activation in WEHI-3 cells. SLE also exhibited antitumor activity in vivo. Our findings showed that SLE may be potentially efficacious in the treatment of leukemia in the future.
\end{abstract}

\section{Introduction}

In Taiwan, 4.32 per 100,000 people die each year of leukemia according to the Department of Health, Executive Yuan, Taiwan in 2010s [1]. Hematopoietic stem cell transplantation, radiotherapy, and chemotherapy agents are usually used in the treatment for leukemia patients, but these outcomes are not fully satisfactory [2]. The most effective strategy for killing cancer cells is to induce cell cycle arrest and apoptosis which plays an important role as an antitumor mechanism in human leukemia cells [3]. Characteristics of apoptosis include chromatin condensation, DNA fragmentation and membrane blebbing, apoptotic bodies, translocation of phosphatidylserine (PS) of the plasma membrane [3-5], caspase 
cascade of cell death signaling on extrinsic, and intrinsicdependent events that regulate proapoptotic and antiapoptotic proteins $[3,6]$. Arresting tumor cells to $G_{0} / G_{1}$ phase and apoptosis may offer therapeutic possibilities for treating malignant tumors $[7,8]$. It is fully reported that reagents which promoted cell cycle arrest or apoptotic induction have been used with medicinal plants $[9,10]$. Numerous studies had been showed that increased consumption of plant-based diet can reduce the risk of cancer [11].

Solanum lyratum Thunberg (Solanaceae), one of the traditional Chinese medicines (TCM) in Taiwan and China is used to regulate immune function [12] and treat allergic responses for generations [13]. Our previous study demonstrated that Solanum lyratum treatment promoted the activity of phagocytosis by macrophages in the peripheral blood mononuclear cells (PBMC) and peritoneal cells from normal and leukemia mice in vivo [14]. We also showed that natural killer (NK) cells from the normal and leukemia mice after SLE treatment can kill the YAC-1 target cells [14]. Therefore, the regulations of immune function might be one of the antitumor mechanisms of SLE in leukemia cells. However, Solanum lyratum is commonly used for treatment of liver, lung esophagus cancer, and leukemia in the Chinese population $[15,16]$. Many studies showed that Solanum lyratum extracts (SLE) inhibited proliferation in human hepatoma BEL-7402 cells, gastric carcinoma SGC-7901 cells, and melanoma A375-S2 cells in vitro and in vivo $[16,17]$. SLE also triggered apoptosis in human cervical cancer HeLa cells through Fas/Fas ligand (FasL) expression [18] promoted the activity of protein kinase A (PKA) in the gastric cancer cells $[19,20]$ and provoked caspase-3-mediated apoptosis in human colon cancer colo 205 cells [21]. Additionally, SLE exhibited antitumor activity through caspase- 8 and caspase- 9 activations and mitogen-activated protein kinase (MAPK) regulation in Lewis lung carcinoma (LLC) cells [22]. The goal of this study hypothesized that whether the antileukemia activity of SLE mediates via its direct cytotoxic effect and explores the molecular mechanisms in WEHI-3 murine leukemia cells. Hence, the study focused on the cell cycle arrest and apoptosis-induced by SLE in the WEHI-3 cells. Based on in vitro and in vivo studies, we found that SLE inhibited cells viability induced cell apoptosis, simultaneously arresting the WEHI- 3 cells to $G_{0} / G_{1}$ phase through regulating activation of $\mathrm{p} 53 / \mathrm{Fas}$ signaling and suppressed allograft tumor in vivo.

\section{Materials and Methods}

2.1. Plant Material and Preparation of Solanum lyratum Extracts (SLE). SLE was obtained from Dr. Chao-Lin Kuo (School of Chinese Pharmaceutical Sciences and Chinese Medicine Resources, China Medical University) as described previously [21]. Solanum lyratum was collected in September 2002 from Dongpu, Sinyi Township, Nantou County, Taiwan. The voucher specimens (CMU SL 0222) were deposited in China Medical University. The $600 \mathrm{~g}$ of Solanum lyratum was extracted frequently with $50 \%$ ethanol at room temperature. The combined all ethanol extracts were filtered and evaporated under reduced pressure then get $58.44 \mathrm{~g}$ of brownish viscous residue. For this experiment, the crude extracts were dissolved in dimethyl sulfoxide (DMSO) [21].

2.2. Chemicals and Reagents. Diosgenin, agarose, 4,6-diamidino-2-phenylindole dihydrochloride (DAPI), dimethyl sulfoxide (DMSO), propidium iodide (PI), Triton X-100, pifithrin- $\alpha$ (PFT $\alpha$; p53 inhibitor), Tris- $\mathrm{HCl}$, and ribonuclease A were obtained from Sigma-Aldrich Corp. (St. Louis, MO, USA). $2^{\prime}, 7^{\prime}$-dichlorodihydrofluorescein diacetate $\left(\mathrm{H}_{2} \mathrm{DCF}-\right.$ DA), 3,3'-Dihexyloxacarbocyanine iodide ( DiOC $_{6}$ ), RPMI1640 medium, L-glutamine, fetal bovine serum (FBS), Trypsin-EDTA, and penicillin/streptomycin were purchased from Invitrogen/Life Technologies (Carlsbad, CA, USA). Caspase-3, -8 , and -9 activity assay kits, caspase-3 specific inhibitor ( $\mathrm{z}-$ Asp-Met-Gln-Asp-fluoromethyl ketone; z-DEVD-fmk), caspase-8-specific inhibitor (z-Leu-Glu-His-Asp-fluoromethyl ketone; z-IETD-fmk), and caspase-9-specific inhibitor (zIle-Glu-Thr-Asp-fluoromethyl ketone; z-LEHD-fmk) were bought from R\&D Systems (Minneapolis, MN, USA). Tdt-mediated deoxyuridine triphosphate nick end labeling (TUNEL) assay kit was purchased from Roche Diagnostics (GmBH, Mannheim, Germany). Annexin V/PI staining kit was bought from Serotec (Raleigh, NC, USA). These primary antibodies (anticaspase-3-FITC, anti-FasL, anti-p53, anticyclin D, anti-CDK4, anti-CDK6, anti-Fas, anti-FADD, anticytochrome c, anti-Apaf-1, anti-Bcl-2, anti-Bcl-xl, anti-Bax, anti-BAD, and anti-GAPDH), and second antibodies for Western blotting were obtained from Santa Cruz Biotechnology, Inc. (Santa Cruz, CA, USA). The primary antibodies (anticaspase-8, anticaspase-9, and anticaspase-3) were obtained from Cell Signaling Technology (Danvers, MA, USA). FITC-conjugated anti-FasL and its FITC-conjugated isotype $\mathrm{mAb}$ were obtained from BD Biosciences Pharmingen (San Diego, CA, USA).

2.3. Determination of Diosgenin from SLE by HPLC. Diosgenin is isolated from SLE as described previously [15, 23]. Standard stock solution containing $5 \mathrm{mg} / \mathrm{mL}$ of diosgenin was prepared by dissolving approximately $3.1 \mathrm{mg}$ of compound in $0.62 \mathrm{~mL}$ methanol. HPLC analysis was performed on SHIMADZU (Japan) two solvent delivery system model CBM-20A together with a model RID-10A refractive index detector. Data acquisition was performed using SHIMADZU Class-VP software. Chromatography was carried out on a Cosmosil 5C-18 MSII column $(250 \times 4.6 \mathrm{~mm}$ i.d. $)$. Isocratic elution was performed with water and HPLC-grade methanol $(10 / 90, \mathrm{v} / \mathrm{v})$ at a flow rate of $1 \mathrm{~mL} / \mathrm{min}$. The solvents were filtered through a $0.45 \mu \mathrm{m}$ of filter prior to use.

2.4. Cell Culture and SLE and Diosgenin Treatment. The murine myelomonocytic leukemia cell line (WEHI-3) was obtained from the Food Industry Research and Development Institute (Hsinchu, Taiwan). Cells were grown in $75-\mathrm{cm}^{2}$ tissue culture flasks at $37^{\circ} \mathrm{C}$ under a humidified $5 \% \mathrm{CO}_{2}$ atmosphere in RPMI 1640 medium containing 10\% FBS, $2 \mathrm{mM}$ L-glutamine, 100 Units/mL penicillin, and $100 \mu \mathrm{g} / \mathrm{mL}$ streptomycin. Exponentially growing cells at $2 \times 10^{5} / \mathrm{mL}$ were 
exposed to different doses of SLE or for different time points. The $0.1 \%$ DMSO is as a vehicle control. Cell morphological examination was determined utilizing a phase-contrast microscope [21].

2.5. Assessment for Cell Viability. Cell viability was determined by a PI exclusion method and flow cytometry [24, 25]. WEHI- 3 cells $\left(2 \times 10^{5}\right.$ cells $\left./ \mathrm{mL}\right)$ in 24 -well plates were incubated with $0,100,200$, and $400 \mu \mathrm{g} / \mathrm{mL}$ of SLE or $0,25,50$, and $100 \mu \mathrm{M}$ of diosgenin for 24,48 and $72 \mathrm{~h}$. For incubation with the inhibitors, cells were pretreated with $10 \mu \mathrm{M}$ of caspase- 3 inhibitor, caspase- 9 inhibitor, and caspase- 8 inhibitor for $1 \mathrm{~h}$, followed by treatment with or without SLE $(200 \mu \mathrm{g} / \mathrm{mL})$ or diosgenin $(50 \mu \mathrm{M})$. At the indicated time courses, cells were collected and then resuspended in PBS containing $4 \mu \mathrm{g} / \mathrm{mL}$ of PI and then analyzed by flow cytometry (FACS Calibur, Becton Dickinson, Franklin Lakes, NJ, USA) [25, 26]. All experiments were performed in triplicate. Percentage of cell viability was calculated as a ratio of SLE- or diosgenin-treated cells.

2.6. Analysis for Cell Cycle Progression by Flow Cytometry. WEHI- 3 cells $\left(2 \times 10^{5}\right.$ cells $\left./ \mathrm{mL}\right)$ in 24 -well flask were exposed to $200 \mu \mathrm{g} / \mathrm{mL}$ of SLE or $50 \mu \mathrm{M}$ of diosgenin for 0,24 , and $48 \mathrm{~h}$. Cells were then collected, fixed in $70 \%$ ethanol overnight, washed in PBS once, and resuspended in $500 \mu \mathrm{L}$ of $192 \mathrm{mM} \mathrm{Na}_{2} \mathrm{HPO}_{4}, 4 \mathrm{mM}$ citric acid, $\mathrm{pH} 7.8$ at $25^{\circ} \mathrm{C}$ for $30 \mathrm{~min}$. The cells were stained with $0.5 \mathrm{~mL}$ of PBS containing $1 \mathrm{mg} / \mathrm{mL}$ RNase, $10 \mu \mathrm{g} / \mathrm{mL}$ PI for $30 \mathrm{~min}$ in the dark and then analyzed by flow cytometry $[27,28]$.

\subsection{Analysis of Apoptotic Cells by DAPI/TUNEL Double Stain-} ing. TUNEL staining was performed according to the manufacturer's protocols (in situ cell death detection kit; Roche Diagnostics). Cells $\left(2 \times 10^{5}\right.$ cells $\left./ \mathrm{mL}\right)$ in 24 -well plates were treated without or with $200 \mu \mathrm{g} / \mathrm{mL}$ of SLE or $50 \mu \mathrm{M}$ of diosgenin for $48 \mathrm{~h}$. Cells were harvested and immediately incubated with working strength terminal deoxynucleotidyl transferase (Tdt) enzyme in a humidified chamber at $37^{\circ} \mathrm{C}$ for $1 \mathrm{~h}$. The cells were immersed in stop/wash buffer and gently rinsed with PBS. FITC-labeled antidigoxigenin antibody was then applied to cells and incubated at $37^{\circ} \mathrm{C}$ for $30 \mathrm{~min}$ in the dark. Cells were washed in PBS, stained with DAPI, and mounted with DABCO (Sigma-Aldrich). DAPIand TUNEL-positive cells were visualized with a fluorescence microscope $[29,30]$.

2.8. Assay of Early Apoptotic Cells by Annexin V/PI Double Staining. Cells $\left(2 \times 10^{5}\right.$ cells $\left./ \mathrm{mL}\right)$ in 24 -well plates were incubated with or without $200 \mu \mathrm{g} / \mathrm{mL}$ of SLE or $50 \mu \mathrm{M}$ of diosgenin for $12 \mathrm{~h}$, the cells were washed twice with PBS and resuspended in binding buffer (10 mM HEPES/NaOH ( $\mathrm{pH} 7.4)$, $140 \mathrm{mM} \mathrm{NaCl}$ and $2.5 \mathrm{mM} \mathrm{CaCl}_{2}$ ). The cells were then stained with fluorescein isothiocyanate (FITC)-Annexin V and PI for $30 \mathrm{~min}$ in the dark at room temperature according to the manufacturer's directions (Serotec Inc., Raleigh, NC, USA). The fluorescence intensity of cells was immediately analyzed by flow cytometry $[21,31,32]$.
2.9. Detection of the Fas Ligand Expression by Flow Cytometry. Fas ligand (FasL) cell surface antigen expression was measured by flow cytometry as previously described $[33,34]$. SLE at $200 \mu \mathrm{g} / \mathrm{mL}$ or diosgenin at $50 \mu \mathrm{M}$ treated cells were rinsed in PBS. FasL was analyzed by direct immunofluorescence staining. FITC-conjugated anti-FasL and its FITC-conjugated isotype mAb (BD Biosciences Pharmingen, San Diego, CA, USA) that were from examined cells were analyzed using a flow cytometer $[33,34]$.

2.10. Treatment with Anti-Fas Ligand (FasL) mAb or Pifithrin$\alpha$ (p53 Inhibitor). Cells $\left(2 \times 10^{5}\right.$ cells $\left./ \mathrm{mL}\right)$ in 24 -well plates were pretreated with $50 \mathrm{ng} / \mathrm{mL}$ of anti-Fas ligand (FasL) $\mathrm{mAb}$ or $10 \mu \mathrm{M}$ of pifithrin- $\alpha$ (p53 inhibitor) for $1 \mathrm{~h}$, followed by treatment with or without $200 \mu \mathrm{g} / \mathrm{mL}$ of SLE or $50 \mu \mathrm{M}$ of diosgenin for $48 \mathrm{~h}$. FasL blocking experiments were performed by treatment with Fas ligand (FasL) mAb (BD Biosciences Pharmingen, San Diego, CA, USA; $500 \mathrm{ng} / \mathrm{mL}$ ) or a mouse IgG1 isotype-matched control mAb (BD Biosciences Pharmingen; $500 \mathrm{ng} / \mathrm{mL}$ ) as previously described $[33,34]$.

2.11. Flow Cytometric Detections of Reactive Oxygen Species (ROS) and Mitochondrial Membrane Potential $\Delta \Psi_{m}$. Cells $\left(2 \times 10^{5}\right.$ cells $\left./ \mathrm{mL}\right)$ in 24 -well plates were exposed to $200 \mu \mathrm{g} / \mathrm{mL}$ of SLE or $50 \mu \mathrm{M}$ of diosgenin for $0,6,12,24$, and $48 \mathrm{~h}$. ROS and $\Delta \Psi_{m}$ were assessed by cell permeable probes $\mathrm{H}_{2}$ DCF-DA $(10 \mu \mathrm{M})$ and $\operatorname{DiOC}_{6}(500 \mathrm{nM})$, respectively. Cells were washed with PBS and resuspended in PBS then analyzed at FL1 channel $(530 \mathrm{~nm})$ by flow cytometry $[26,28]$.

2.12. Immunofluorescence Staining. Cells $\left(2 \times 10^{5}\right.$ cells $\left./ \mathrm{mL}\right)$ in 4-well chamber slides were incubated with SLE $(200 \mu \mathrm{g} / \mathrm{mL})$ or diosgenin $(50 \mu \mathrm{M})$ for $48 \mathrm{~h}$. After SLE treatment, cells were fixed with iced methanol, blocked with $2 \%$ BSA, stained with anticaspase- 3 monoclonal antibodies (Santa Cruz Biotechnology, Inc.) and then FITC-conjugated anti-mouse IgG antibody (Santa Cruz Biotechnology, Inc.). The cells were analysed with a fluorescence microscope $[35,36]$.

2.13. Caspase- 8 and Caspase- 9 Activities Assay. Cells (total $2.5 \times 10^{6}$ cells) in 6 -well plates were treated with $200 \mu \mathrm{g} / \mathrm{mL}$ of SLE or $50 \mu \mathrm{M}$ of diosgenin for $0,12,24,36$, and $48 \mathrm{~h}$. Cells were harvested and lysed in a lysis buffer $(50 \mathrm{mM}$ Tris$\mathrm{HCl}$ (pH 7.4), 1 mM EDTA, 10 mM EGTA, 10 mM digitonin, and $2 \mathrm{mM}$ DTT). Cell lysates (50 $\mu$ g protein) were incubated with caspase- 9 and -8 specific substrates (Ac-LEHD-pNA, and Ac-IETD-pNA) (R\&D Systems, Inc., Minneapolis, MN, USA) for $1 \mathrm{~h}$ at $37^{\circ} \mathrm{C}$. The caspase activity was determined by measuring $\mathrm{OD}_{405}$ of the released pNA $[35,37]$.

2.14. Western Blotting Analysis. Cells (total $1 \times 10^{7}$ cells) in 75 -T flask were incubated with or without SLE $(200 \mu \mathrm{g} / \mathrm{mL})$ or diosgenin $(50 \mu \mathrm{M})$ for $0,12,24$, and $48 \mathrm{~h}$. Total protein was prepared and determined as previously described [21, 27]. Protein lysates were sonicated and the supernatants were boiled in SDS sample buffer for $5 \mathrm{~min}$. The protein 
concentration was measured by using a BCA assay kit (Pierce Chemical, Rockford, IL, USA). Equal amounts of cell lysate were run on 10 to $12 \%$ SDS-polyacrylamide gel electrophoresis and electrotransferred to a nitrocellulose membrane by using the iBot Dry Blotting System (Invitrogen/Life Technologies). The transferred membranes were blocked for $1 \mathrm{~h}$ in 5\% nonfat dry milk in Tris-buffered saline/Tween 20 and incubated with primary antibodies at $4^{\circ} \mathrm{C}$ overnight. Membranes were washed three times with Tris-buffered saline/Tween 20 for $10 \mathrm{~min}$ and incubated with secondary HRPconjugated antibody $[25,29,38]$. The blots were developed by using an ECL kit and Kodak Bio-MAX MR film (Eastman Kodak, Rochester, NY, USA).

\subsection{WEHI-3 Murine Leukemia Cells Allograft Model and In} Vivo Antitumor Activity Assay. Eighteen BALB/c mice (4-6 weeks of age) were obtained from the National Laboratory Animal Center (NLAC, Taipei, Taiwan). All mice were fed a commercial diet and water. WEHI- 3 cells (total $1 \times 10^{7}$ cells) were resuspended in serum-free RPMI medium 1640 with BD Matrigel basement membrane matrix (BD Biosciences) at a $1: 1$ ratio (total volume $200 \mu \mathrm{L}$ ). WEHI-3 cells were subcutaneously injected into the flanks of mice. Tumor mass was measured every 4 days. When tumors reached an approximate volume of $100 \mathrm{~mm}^{3}$, mice were selected and distributed for drug studies (day 0). Animals with tumors were randomly assigned to three treatment groups. Animals (six mice/group) were given vehicle control (olive oil), SLE (5 and $15 \mathrm{mg} / \mathrm{kg}$ ) by oral gavage for QD treatment [14]. Body weight and tumors volume were measured every 4 days with a caliper. Tumor volumes were determined by measuring the length $(l)$ and the width $(w)$, and the volumes were calculated as $l / w^{2} / 2$. The mice were sacrificed when the tumor burden was less than $1800 \mathrm{~mm}^{3}$ (day 28) [39-42]. All experiments were conducted according to the Institutional Animal Care and Use Committee (IACUC; Affidavit of Approval of Animal Use Protocol, No. 98-129-N), China Medical University (Taichung, Taiwan).

2.16. Statistical Analysis. All the statistical results were expressed as the mean \pm S.E.M. of triplicate samples. Statistical analyses of data were done using one-way ANOVA followed by Student's $t$-test, and $P<0.05$ were considered significant.

\section{Results}

3.1. HPLC Analysis in SLE. The previous studies have demonstrated that diosgenin is one of the major components of the SLE $[15,23]$. HPLC chromatogram of SLE analyzed using a Cosmosil 5C-18 MSII column $(250 \times 4.6 \mathrm{~mm}$ i.d. $)$ eluted with methanol/water $(90 / 10, v / v)$ at a flow rate of $1.0 \mathrm{~mL} / \mathrm{min}$ and with refractive index detector. The peak at 24.140 min was identified as diosgenin as seen in Figure 1.

3.2. SLE and Diosgenin Inhibited Cell Proliferation, Promoted $G_{0} / G_{1}$ Phase Arrest, and Induced Cell Death in WEHI-3 Cells. We initially assessed the cell viability in WEHI-3 cells. In Figure 2(a), the concentrations of 100,200 , and $400 \mu \mathrm{g} / \mathrm{mL}$ of SLE or 25,50 , and $100 \mu \mathrm{M}$ of diosgenin decreased the percentage of viable cells, and these effects are in a concentration-dependent manner. The half maximal (50\%) inhibitory concentration $\left(\mathrm{IC}_{50}\right)$ for a $48 \mathrm{~h}$ treatment of SLE and diosgenin in WEHI-3 cell was $198.35 \pm 2.64 \mu \mathrm{g} / \mathrm{mL}$ and $50.32 \pm$ $1.45 \mu \mathrm{M}$, respectively. Therefore, SLE at $200 \mu \mathrm{g} / \mathrm{mL}$ or diosgenin at $50 \mu \mathrm{M}$ was selected for further experiments in this study. In addition, both reagents induced the strong growthinhibitory and cell death effects in WEHI-3 cells. The further studies were conducted to investigate the possible mechanisms addressing cell cycle arrest or cell death by inhibitory effects in SLE- and diosgenin-treated WEHI-3 cells. Our results demonstrated that SLE and diosgenin induced $\mathrm{G}_{0} / \mathrm{G}_{1}$ phase arrest and cell death (sub-G1 phase) in 24 and $48 \mathrm{~h}$ treatments, and these effects occurred in a time-dependent manner (Figure 2(b)).

3.3. SLE and Diosgenin Induced Apoptotic Death and Caspase3 Activation in WEHI-3 Cells. To determine whether SLE and diosgenin can induce cell apoptosis, WEHI-3 cells treated with $200 \mu \mathrm{g} / \mathrm{mL}$ of SLE or $50 \mu \mathrm{M}$ of diosgenin in WEHI-3 cells for $12 \mathrm{~h}$ triggered the translocation of phosphatidylserine (PS) from inner side of the plasma membrane to the outer layer of the cell membrane which was examined by Annexin V/PI analysis (Annexin positive cells: $32.89 \pm 2.26 \%$ and $41.93 \pm 3.50 \%$ ) as shown in Figure 3(a). Figure 3(b) showed that chromatin condensation and DNA fragmentation were evident in WEHI-3 cells treated with $200 \mu \mathrm{g} / \mathrm{mL}$ of SLE or $50 \mu \mathrm{M}$ of diosgenin for $48 \mathrm{~h}$. To investigate if SLE- and diosgenin-induced apoptosis is mediated through caspase-3dependent pathway, WEHI-3 cells were treated with or without SLE $(200 \mu \mathrm{g} / \mathrm{mL})$ or diosgenin $(50 \mu \mathrm{M})$ for $48 \mathrm{~h}$ and then stained with anticaspase- 3 antibody. Our results shown in Figure 3(c) indicated that the level of caspase-3 was increased in nuclei in WEHI-3 cells after exposure to SLE or diosgenin. Cells were pretreated with caspase-3 specific inhibitor ( $\mathrm{z}$ DEVD-fmk) and then exposed to SLE or diosgenin. Results showed that there is a significant increase of cell viability in comparison to SLE and diosgenin (Figure 3(d)) treatment alone sample. Our findings suggest that SLE- and diosgenininduced apoptosis was involved in caspase-3-dependent pathway in WEHI-3 cells.

3.4. SLE and Diosgenin Induced Apoptosis through Extrinsic Apoptotic Pathway in WEHI-3 Cells. It is well known that caspase- 3 can be activated in two major apoptotic pathways, the death-receptor (extrinsic pathway), and mitochondria-mediated (intrinsic pathway) pathways $[3,6]$. Our results showed that SLE- and diosgenin-induced apoptosis might be through caspase-3-dependent signaling (Figures 3(c) and $3(\mathrm{~d})$ ). Thus, we determined whether the death receptor (extrinsic pathways) contributes to SLE- and diosgenin-induced apoptosis. Figure $4(\mathrm{a})$ indicates that SLE $(200 \mu \mathrm{g} / \mathrm{mL})$ and diosgenin $(50 \mu \mathrm{M})$ treatments time dependently caused caspase- 8 activity. Cells were pretreated with caspase-8-specific inhibitor (z-IETD-fmk) and then exposed to SLE or diosgenin, the result showed that there is a significant decrease in caspase- 8 activity (Figure $4(\mathrm{a})$ ) and an increase in cell viability (Figure $4(\mathrm{~b})$ ) in comparison to SLE or diosgenin 


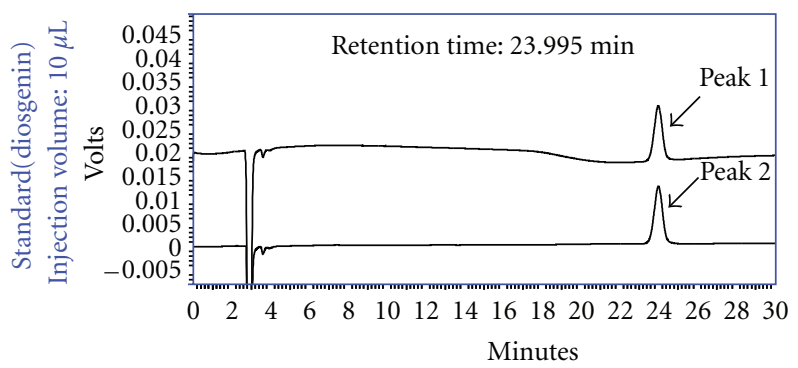

(a)

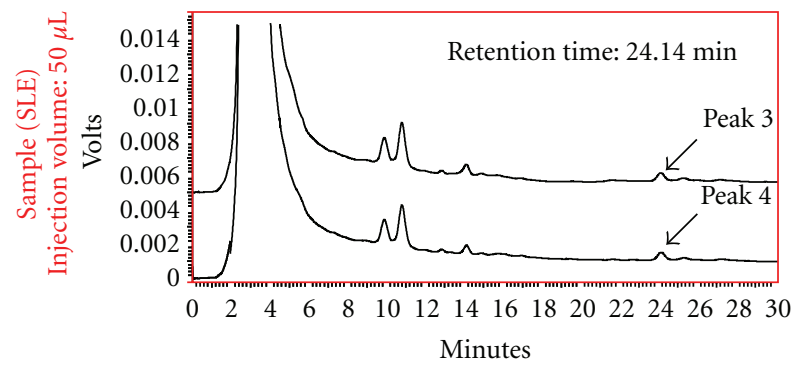

(b)

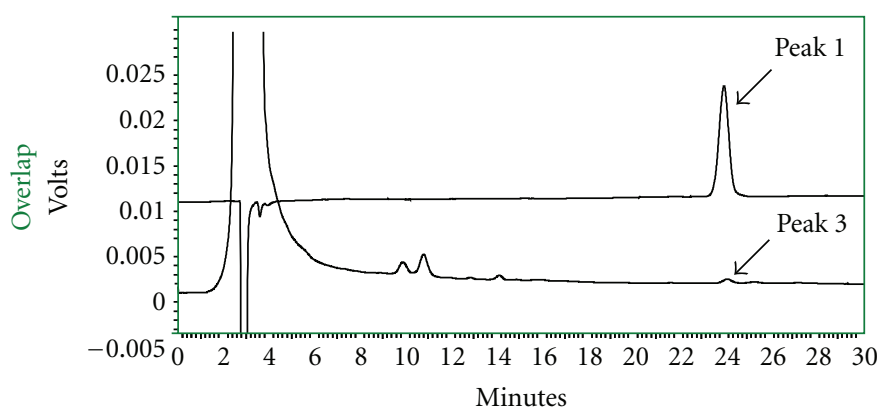

(c)

FIGURE 1: The content of diosgenin in SLE was analyzed by HPLC. HPLC was performed on SHIMADZU (Japan) two solvent delivery system model CBM-20A together with a model RID-10A refractive index detector. Data acquisition was performed using SHIMADZU Class-VP software. Chromatography was carried out on a Cosmosil 5C-18 MSII column $(250 \times 4.6 \mathrm{~mm}$ i.d.). Isocratic elution was performed with water and HPLC-grade methanol (10/90, v/v) at a flow rate of $1 \mathrm{~mL} / \mathrm{min}$. Pure diosgenin (peak 1 and peak 2) showed a retention time at $23.995 \mathrm{~min}$ (top), SLE (peak 3 and peak 4) showed a retention time at $24.140 \mathrm{~min}$. (middle) and overlapping analysis (bottom).

\begin{tabular}{|c|c|c|}
\hline \multicolumn{3}{|c|}{ The half maximal inhibitory concentration $\left(\mathrm{IC}_{50}\right)$ of SLE and diosgenin } \\
\hline Time & SLE $(\mu \mathrm{g} / \mathrm{mL})$ & Diosgenin $(\mu \mathrm{M})$ \\
\hline $48 \mathrm{~h}$ & $198.35 \pm 2.64$ & $50.32 \pm 1.45$ \\
\hline
\end{tabular}

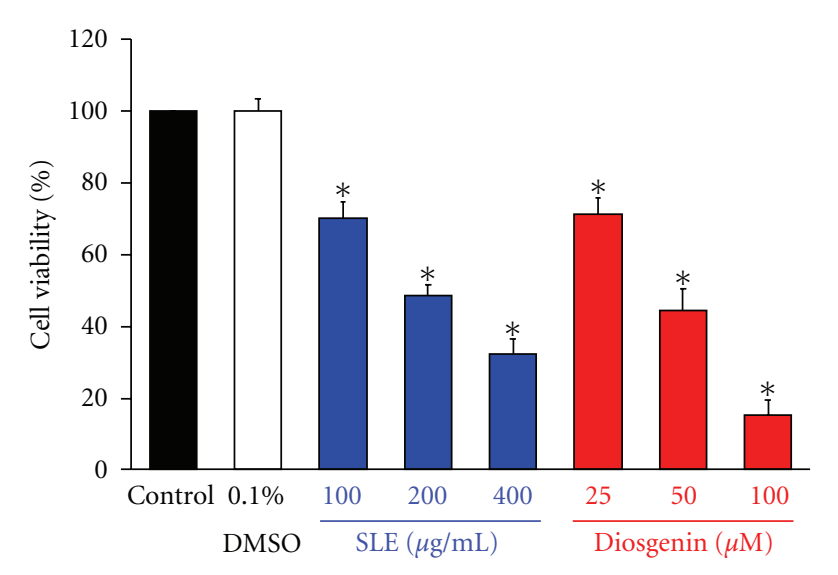

(a)

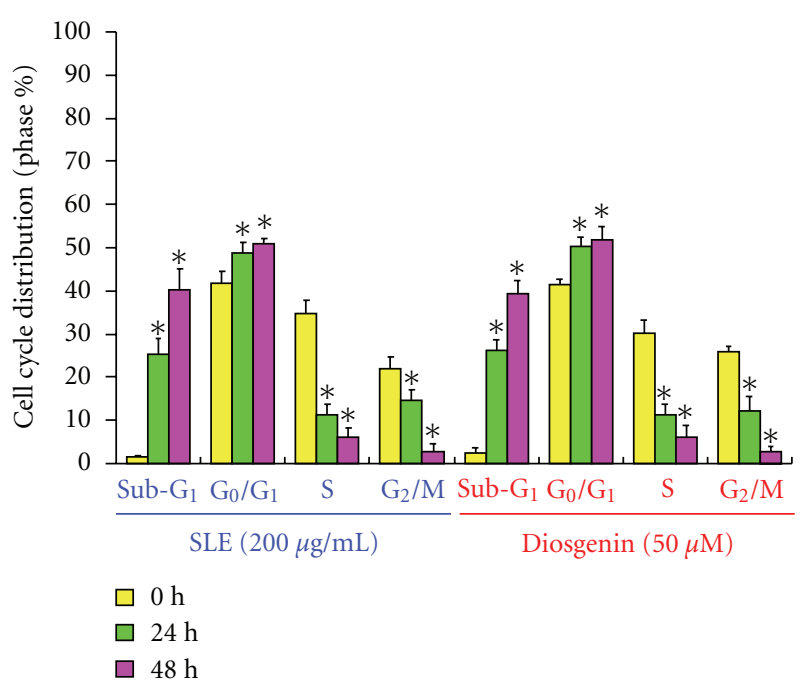

(b)

FIGURE 2: The effects of SLE and diosgenin on cell viability and cell cycle distribution in WEHI-3 cells. (a) Cells were treated with SLE (0, 100, 200 , and $400 \mu \mathrm{g} / \mathrm{mL})$ or diosgenin $(0,25,50$, and $100 \mu \mathrm{M})$ for $48 \mathrm{~h}$. Percentage of viable cells was determined by PI exclusion method. Data are presented as the mean \pm S.E.M. of three independent experiments. ${ }^{*}, P<0.05$, significantly different compared with control treatment. (b) Cells were treated with $200 \mu \mathrm{g} / \mathrm{mL}$ of SLE or $50 \mu \mathrm{M}$ of diosgenin for 24 and $48 \mathrm{~h}$. The cell cycle distribution was determined using flow cytometric analysis and cell cycle distribution was quantified. Data are presented as the mean \pm S.E.M. of three independent experiments. * $P<0.05$, significantly different compared with $0 \mathrm{~h}$ treatment. 


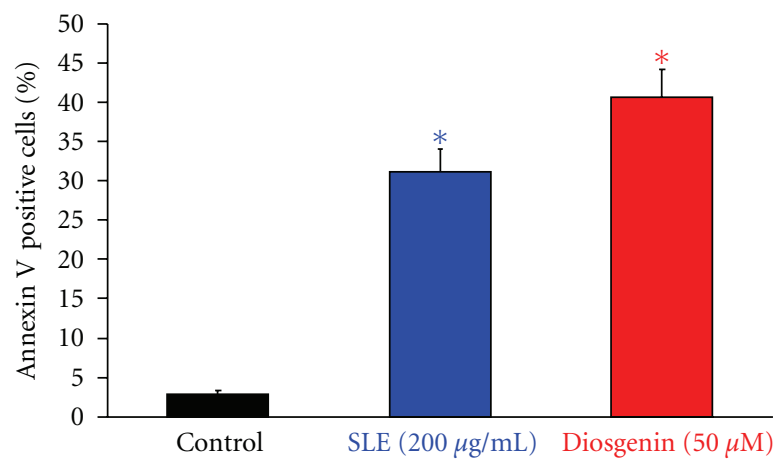

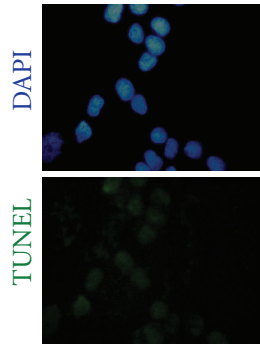

Control

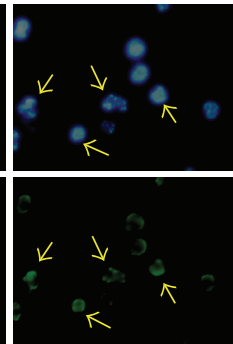

$\operatorname{SLE}(200 \mu \mathrm{g} / \mathrm{mL})$

(b)

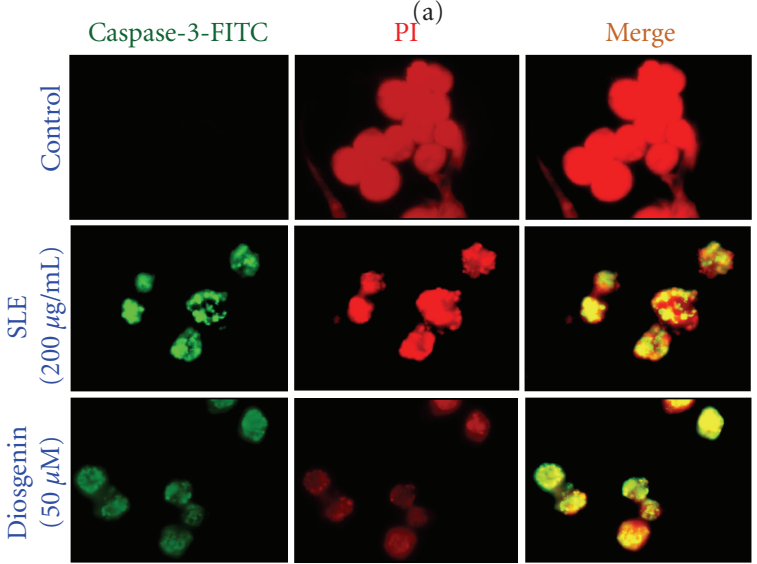

(c)

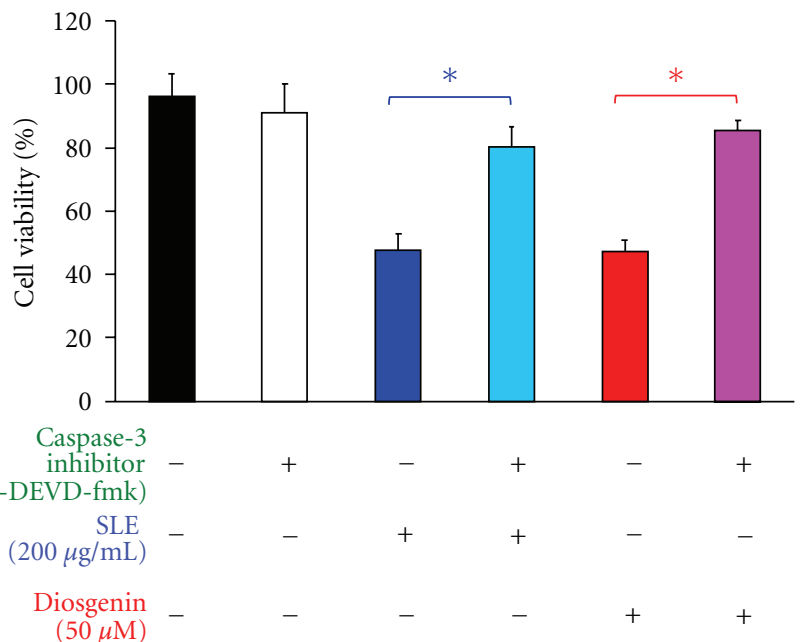

(d)

FIGURE 3: SLE- and diosgenin-induced apoptosis and caspase-3 activation in WEHI-3 cells. Cells were treated with $200 \mu \mathrm{g} / \mathrm{mL}$ of SLE or $50 \mu \mathrm{M}$ of diosgenin for $12 \mathrm{~h}$. (a) Annexin V/PI analysis was determined by flow cytometric assay. Apoptotic cell population (Annexin $\mathrm{V}$ positive cells) was quantified as described in materials and methods. Data are presented as the mean \pm S.E.M. of three independent experiments. ${ }^{*}, P<0.05$, significantly different compared with control treatment. Cells were treated with $200 \mu \mathrm{g} / \mathrm{mL}$ of SLE or $50 \mu \mathrm{M}$ of diosgenin for $48 \mathrm{~h}$. (b) DAPI/TUNEL analysis and (c) caspase-3 protein location were determined by immunostaining and photographed by fluorescence microscopic systems as described in materials and methods (400X) ( $\uparrow \mathrm{DNA}$ fragmentation). (d) Cells were pretreated with specific inhibitor of caspases-3 (z-DEVD-fmk) for $1 \mathrm{~h}$ after exposure to SLE $(200 \mu \mathrm{g} / \mathrm{mL})$ or diosgenin $(50 \mu \mathrm{M})$ for $48 \mathrm{~h}$ exposure. The cells were collected to determine the percentage of viable cells. Data are presented as the mean \pm S.E.M. of three independent experiments. ${ }^{*}$, $P<0.05$, significantly different compared with SLE-treated cells.

treatments alone sample. Figure $4(\mathrm{c})$ revealed that FasL protein level was increased in SLE- and diosgenin-treated WEHI-3 cells by flow cytometry. It is reported that p53inducible proapoptotic genes triggered apoptosis through death-receptor apoptotic pathway $[43,44]$. Cells were pretreated with p53 inhibitor (pifithrin- $\alpha$; PFT $\alpha$ ) or anti-FasL $\mathrm{mAb}$ and then exposed to SLE or diosgenin. Figure 4(d) showed that there is a significant increase in cell viability when in comparison to SLE- or diosgenin-treated alone samples. Our results suggest that SLE- and diosgenin-induced apoptosis might fully carried out through p53-mediated extrinsic apoptotic pathways in WEHI-3 cells.

\subsection{SLE and Diosgenin Triggered Apoptosis through Intrinsic} Pathway in WEHI-3 Cells. We determined the mitochondrial apoptotic signals if contribute to SLE- or diosgenin-induced apoptosis. In Figure 5(a), the results showed that SLE $(200 \mu \mathrm{g} / \mathrm{mL})$ or diosgenin $(50 \mu \mathrm{M})$ stimulated caspase-9 activity in a time-dependent effect in WEHI-3 cells. Cells were pretreated with caspase-9-specific inhibitor (z-LEHD-fmk) and then exposed to SLE or diosgenin, the result showed that there is a significant decrease in caspase- 9 activity (Figure 5(a)) and an increase in cell viability (Figure 5(b)) in comparison to SLE or diosgenin treatments alone cells. We examined the effects of SLE and diosgenin on the ROS production and $\Delta \Psi_{m}$. Both reagents promoted ROS production (Figure 5(c)) and loss of $\Delta \Psi_{m}$ (Figure 5(d)) after $12 \mathrm{~h}$ treatment in WEHI-3 cells. Cells were pretreated with $\mathrm{N}$-acetylcysteine (NAC, ROS scavenger) and treated with SLE. We found that the increased the percentage of viable WEHI-3 cells occurred when compared SLE and diosgenintreated cells (data not shown). Our findings proposed that 

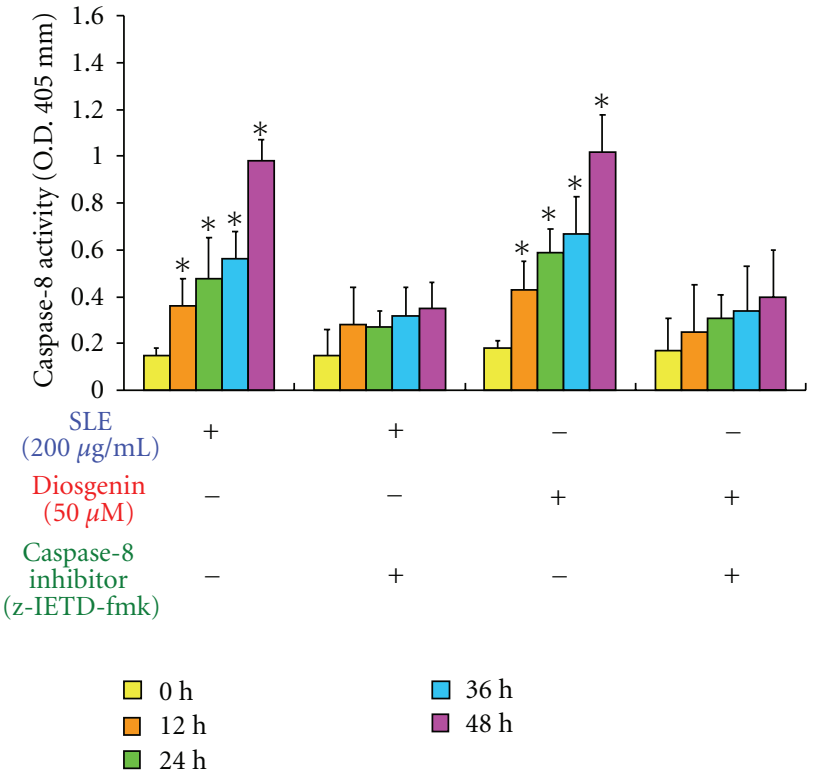

(a)

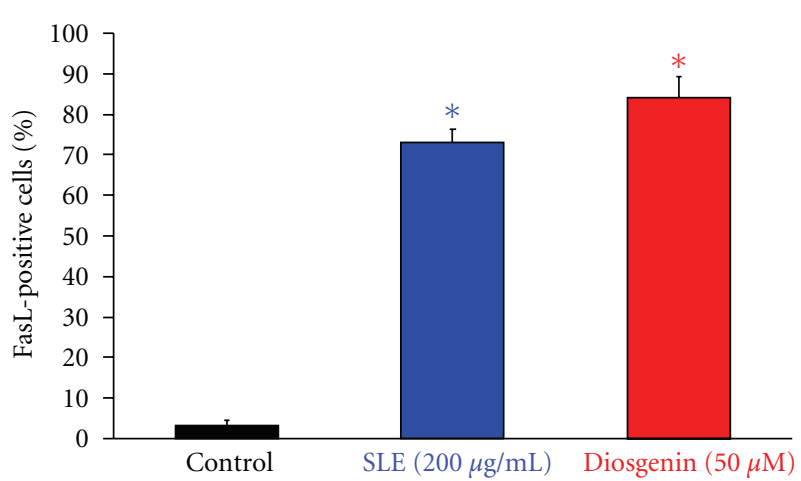

(c)

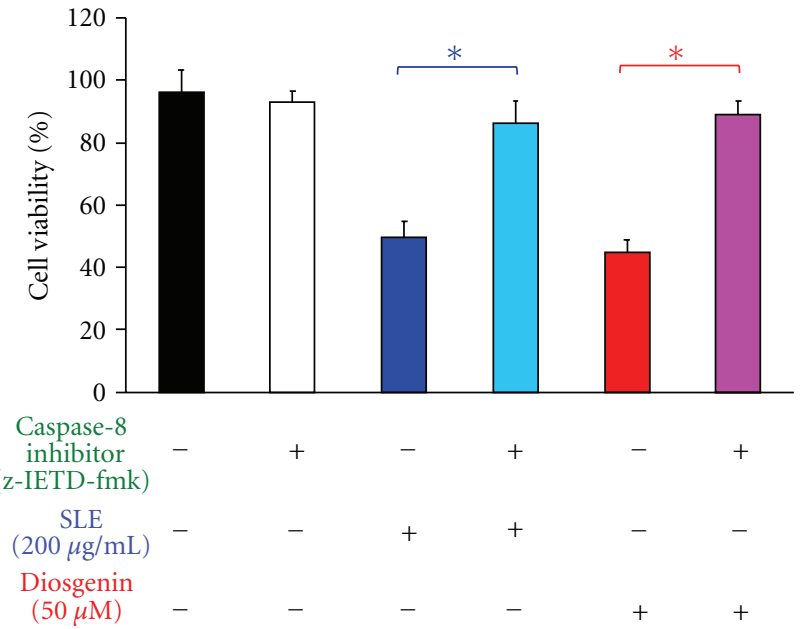

(b)

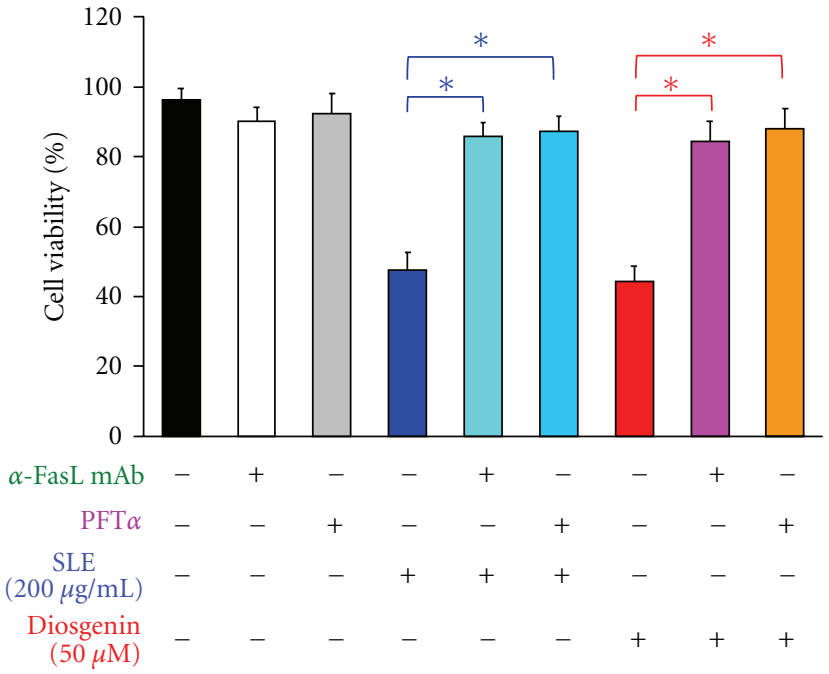

(d)

FIGURE 4: Effects of SLE and diosgenin on WEHI-3 cells in the extrinsic apoptotic pathway. Cells were pretreated with specific inhibitors of caspases-8 (z-IETD-fmk) for $1 \mathrm{~h}$ after exposure to SLE $(200 \mu \mathrm{g} / \mathrm{mL})$ or diosgenin $(50 \mu \mathrm{M})$ for 12, 24, 36, and $48 \mathrm{~h}$. (a) The whole-cell lysates were subjected to caspase- 8 activity and (b) cells were collected after SLE or diosgenin for a $48 \mathrm{~h}$ treatment to determine the percentage of viable cells. (c) Cells were incubated with $200 \mu \mathrm{g} / \mathrm{mL}$ of SLE or $50 \mu \mathrm{M}$ of diosgenin for $24 \mathrm{~h}$, and FasL protein expression was detected by immunostaining and analysis by flow cytometry. (d) Cells were pretreated with anti-FasL mAb or specific inhibitor of p53 (PFT $\alpha$ ) for $1 \mathrm{~h}$ after exposure to SLE $(200 \mu \mathrm{g} / \mathrm{mL})$ or diosgenin $(50 \mu \mathrm{M})$ for a $48 \mathrm{~h}$ exposure. Cells were collected to determine the percentage of viable cells. Data are presented as the mean \pm S.E.M. of three independent experiments. ${ }^{*}, P<0.05$, significantly different compared with SLE-treated cells.

SLE- and diosgenin-induced apoptosis was through ROS production and intrinsic pathways in WEHI-3 cells.

3.6. Effects of SLE and Diosgenin on $G_{0} / G_{1}$ Phase and Apoptosis-Associated Protein Levels in WEHI-3 Cells. We investigated the protein levels of the $\mathrm{G}_{0} / \mathrm{G}_{1}$ phase and apoptosis by Western blotting. As shown in Figure 6(a), SLE and diosgenin caused an increase in the protein level of p53 and decreased the protein levels of CDK4, CDK6, and cyclin $\mathrm{D}$ in WEHI-3 cells. Results shown in Figure 6(b) indicated that SLE and diosgenin increased the death receptor pathway-associated protein levels, including Fas/CD95, FasL, FADD, and cleavage-caspase-8. Furthermore, mitochondrial pathway-related protein levels (cytochrome $c$, Apaf-1, Bax, $\mathrm{Bad}$, and cleavage-caspase-9) were increased, but the levels of $\mathrm{Bcl}-2$ and $\mathrm{Bcl}-\mathrm{xl}$ were decreased in SLE and diosgenin-treated WEHI-3 cells (Figure 6(c)). 


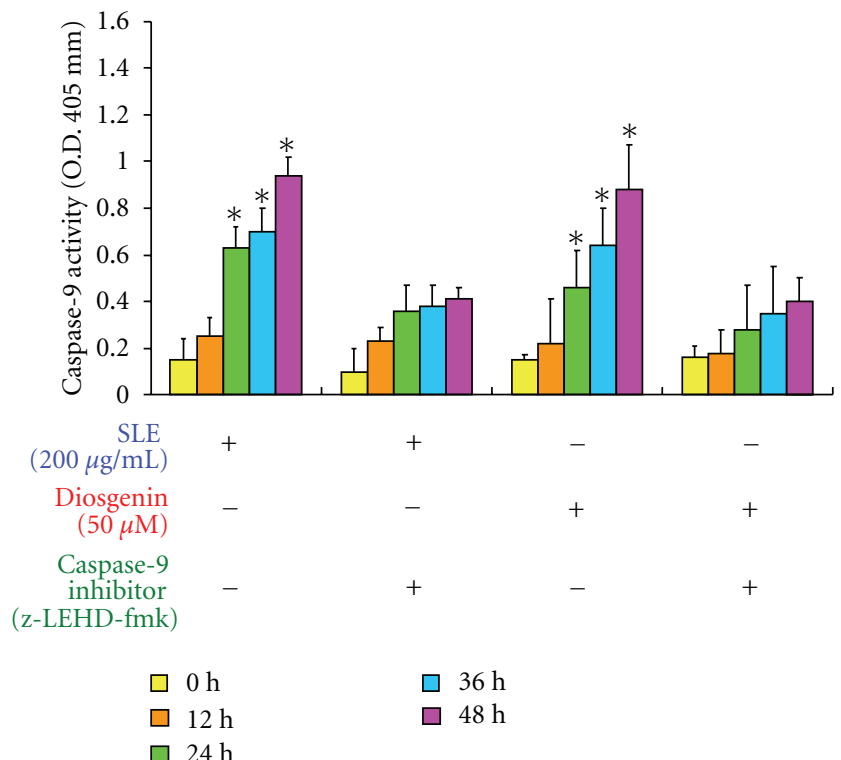

(a)

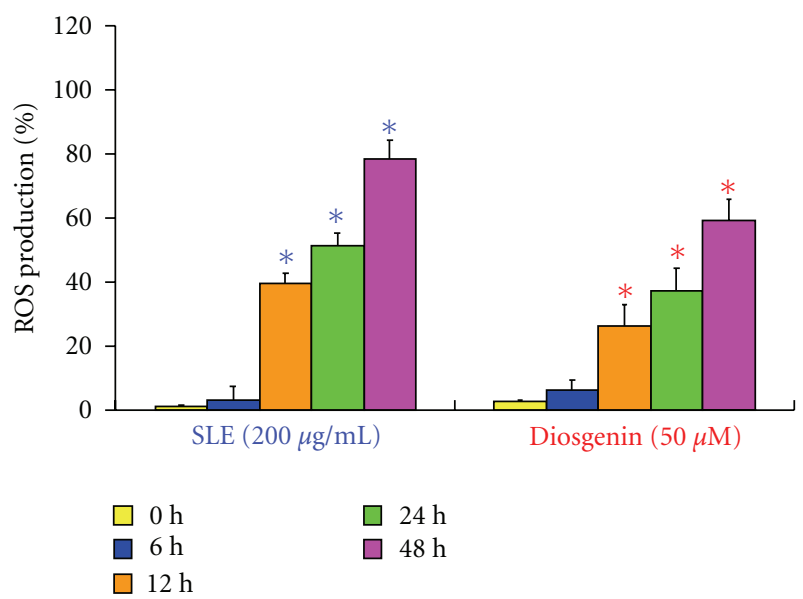

(c)

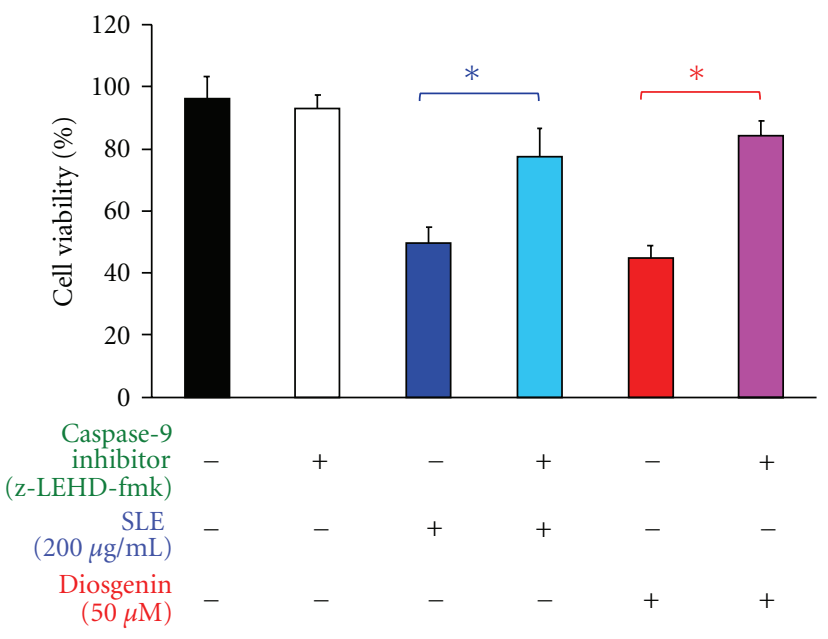

(b)

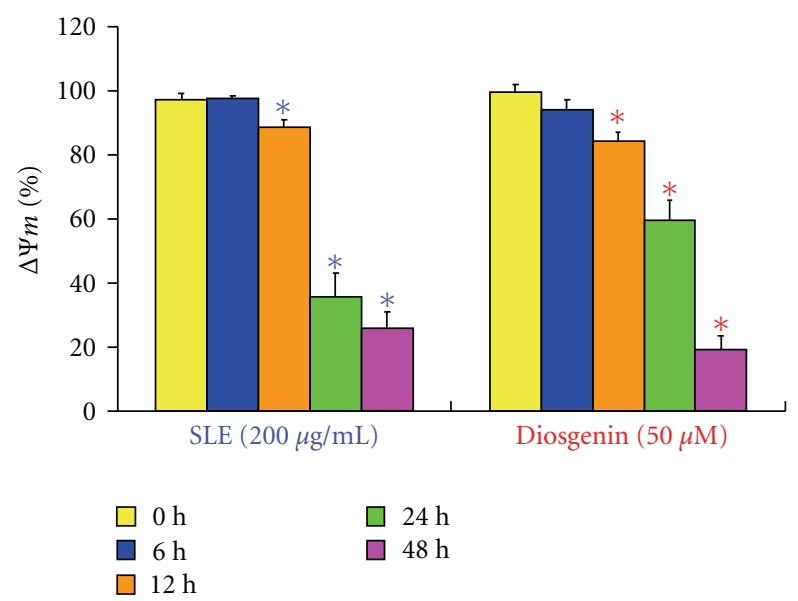

(d)

FIGURE 5: Effects of SLE and diosgenin on WEHI-3 cells in the intrinsic apoptotic pathway. Cells were pretreated with specific inhibitor of caspases-9 (z-LEHD-fmk) for $1 \mathrm{~h}$ after exposure to SLE $(200 \mu \mathrm{g} / \mathrm{mL})$ or diosgenin $(50 \mu \mathrm{M})$ for 12,24 , 36, and $48 \mathrm{~h}$. (a) The whole-cell lysates were subjected to caspase- 9 activity assay and (b) cells were collected after SLE or diosgenin for a $48 \mathrm{~h}$ treatment to determine the percentage of viable cells. Data are presented as the mean \pm S.E.M. of three independent experiments. ${ }^{*}, P<0.05$, significantly different compared with SLE treatment. (c) The reactive oxygen species (ROS) of SLE- or diosgenin-treated WEHI-3 cells from each time point were measured by staining with $\mathrm{H}_{2}$ DCF-DA. (d) The mitochondrial membrane potential $\left(\Delta \Psi_{m}\right)$ of both reagents-treated WEHI-3 cells was measured by staining with $\mathrm{DiOC}_{6}$. Data are presented as the mean \pm S.E.M. of three independent experiments. ${ }^{*}, P<0.05$, significantly different compared with $0 \mathrm{~h}$ treatment.

3.7. Antitumor Activity of SLE in WEHI-3 Cells Allograft Model. Based on our in vitro studies, we examined the in vivo antitumor activities of SLE in a BALB/c mouse WEHI- 3 allograft model [42]. Representative tumor weights from the WEHI-3 allograft mice treated with or without SLE were shown in Figure 7(a) and 7(b). SLE (15 mg/kg; QD; oral) significantly decreased the tumor weight by $56.84 \%$ compared with control mice. As seen in Figure 7(c), SLE (5 and $15 \mathrm{mg} / \mathrm{kg}$; QD; oral) reduced tumor volume compared with control after treatment from day 12 to 28. Figure 7(d) shows that the body weights of the allograft mice were not significantly different after treatment with SLE (5 and $15 \mathrm{mg} / \mathrm{kg}$; QD; oral) from day 0 to 28 . SLE significantly prevented the loss of body weight compared with the control group. Our results proposed that SLE reduced the tumor size and processed antitumor activity in the WEHI-3 allograft model.

\section{Discussion}

Traditional Chinese medicines (TCM) were appiled to prevent or therapy various tumor are marked with their high 


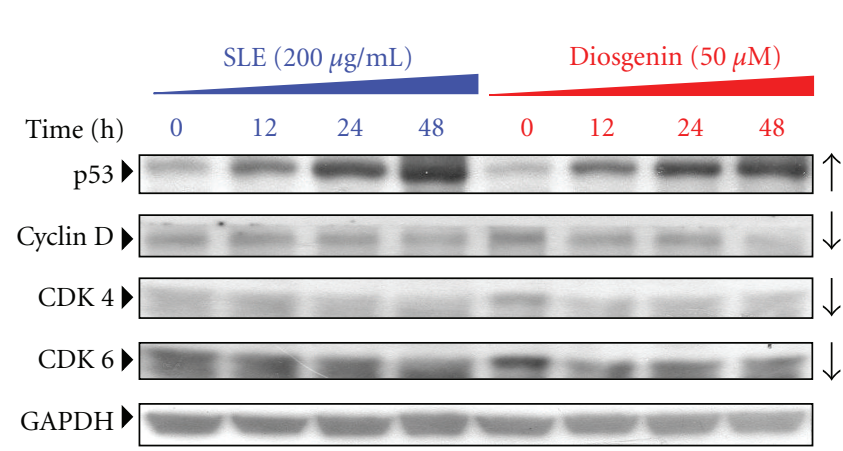

(a)

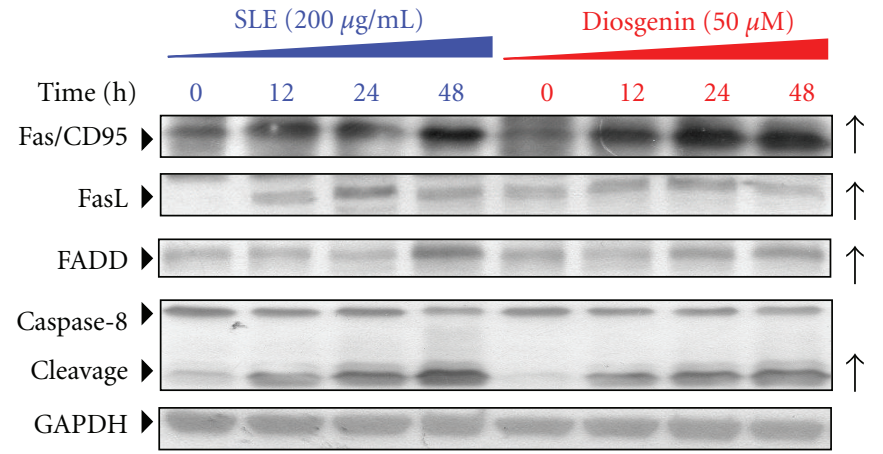

(b)

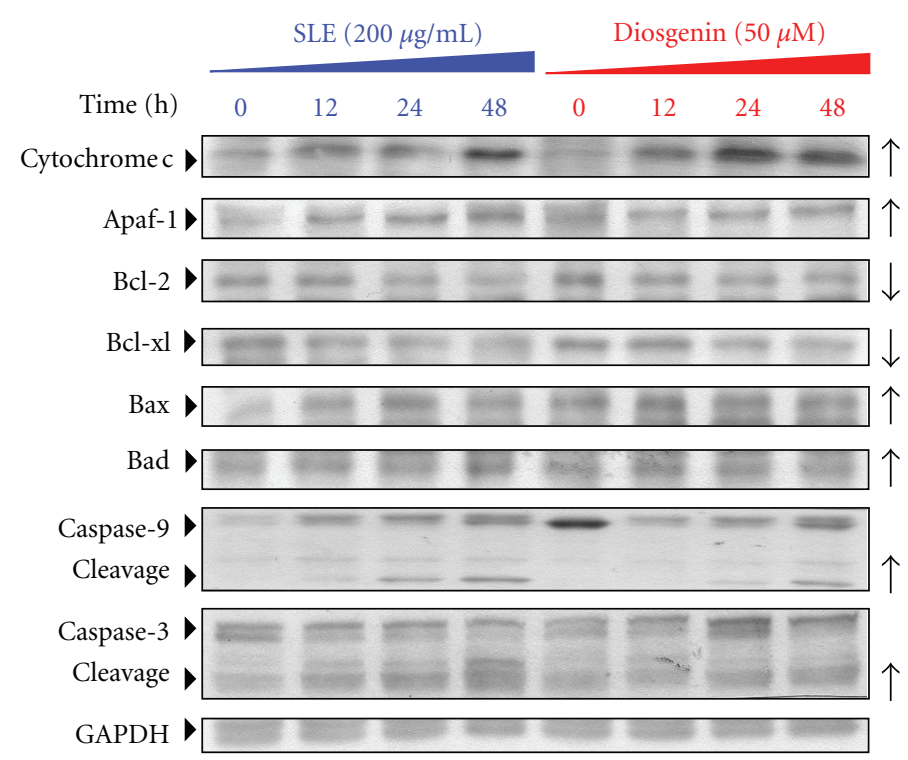

(c)

FIgURE 6: SLE and diosgenin altered the levels of $\mathrm{G}_{0} / \mathrm{G}_{1}$ phase and apoptotic relative proteins in WEHI-3 cells. Cells were exposed to SLE $(200 \mu \mathrm{g} / \mathrm{mL})$ or diosgenin $(50 \mu \mathrm{M})$ and then incubated for 12, 24, and $48 \mathrm{~h}$. The protein levels of (b) p53, cyclin D, CDK4, and CDK6, (b) Fas/CD95, FasL, FADD, Caspase-8, and GAPDH (b), and (c) cytochrome $c$, Apaf-1, Bcl-2, Bcl-xl, Bax, Bad, caspase-9, caspase-3, and GAPDH in SLE-treated WEHI-3 cells were determined by Western blotting. Data are presented as the mean \pm S.E.M. of three independent experiments. ${ }^{*}, P<0.05$, significantly different compared with 0 h treatment.

antitumor activity but low toxicity in normal cells $[9,10]$. SLE is an active TCM with various immune and pharmacological effects on antitumor activity [14-16]. Our earlier study has verified that SLE affected immune response in vivo [14]. Herein, we further evaluated the antileukemia effects of SLE and diosgenin on WEHI-3 cells in vitro. Our results demonstrated that SLE significantly inhibited the viability in WEHI-3 cells (Figure 2(a)). Importantly, SLE had a relative low toxicity effect in normal PBMC cells, which suggested that SLE might be an effective and safe antitumor reagent [14]. In our study, the inhibition of tumor growth effect of SLE on the WEHI-3 cell allograft model in the SLE-treated mice was observed (Figure 7). Due to these observations, SLE is safety as a leukemia therapeutic reagent. In addition, our novel findings showed that SLE exhibited two important mechanisms in antileukemia effects; one is immune regulation [14] and the other is direct cytotoxicity effects and cell growth through induction of $\mathrm{G}_{0} / \mathrm{G}_{1}$ phase arrest and apoptosis in WEHI-3 cells.

It has been reported that several mechanisms for SLEmediated inhibition of tumor cell survival and induction of apoptosis occurred in human cancer cells [16-21]. In our previous study, production of ROS in colo 205 colon cancer cells after SLE treatment might be involved in a direct anticancer effect, inhibition of cell proliferation and induction of apoptosis [21]. Herein, we characterized the effects of SLE on WEHI-3 cells. Modulation of expression and function of cell cycle regulatory proteins such as cyclin-dependent kinase inhibitor (CKI), cyclins, and CDK provides a crucial mechanism for the control of cell growth $[45,46]$. In regulation of transition from $\mathrm{G}_{1}$ to $\mathrm{S}$, activation of CDK4, CDK6, and cyclin $\mathrm{D}$ is one of the important mechanisms [47]. SLE induced $\mathrm{G}_{0} / \mathrm{G}_{1}$ phase arrest (Figure $2(\mathrm{~b})$ ) and inhibited the cyclin D, CDK4, and CDK6 protein levels, but it exhibited 


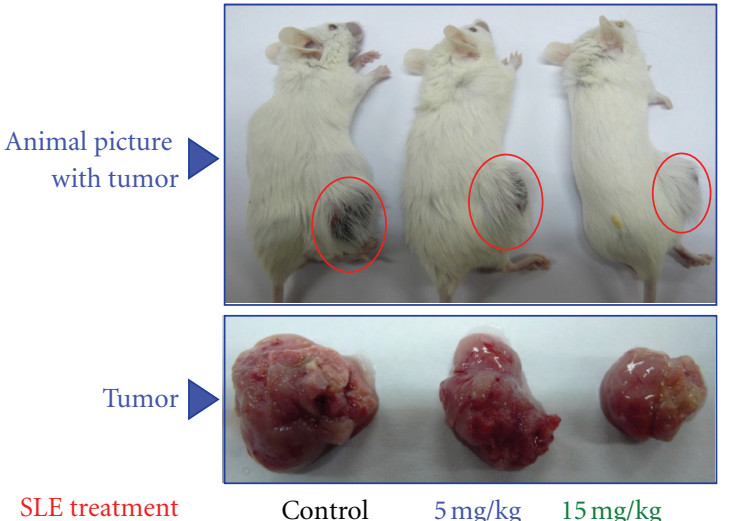

(a)

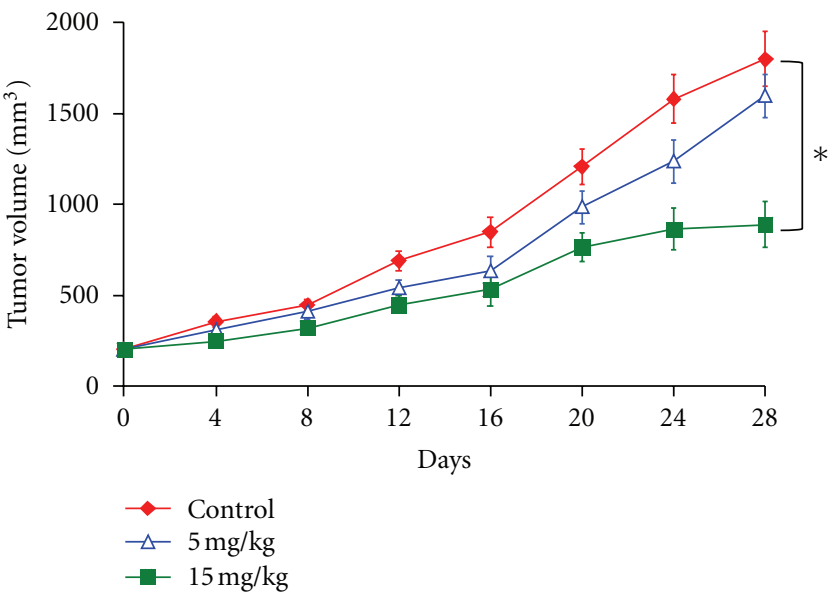

(c)

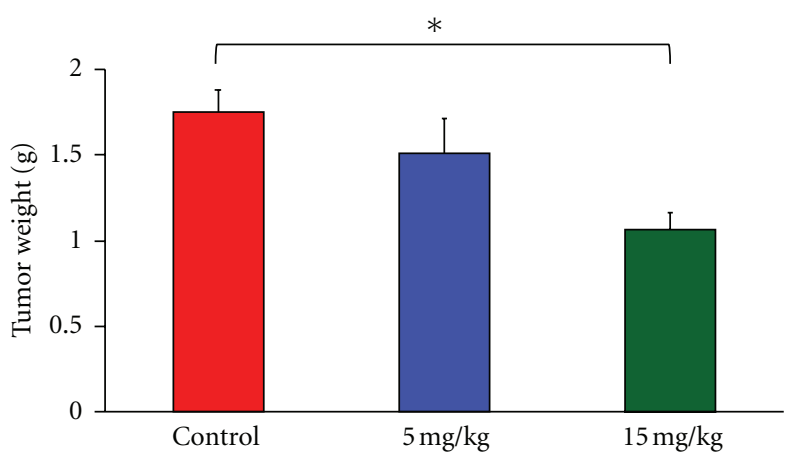

(b)

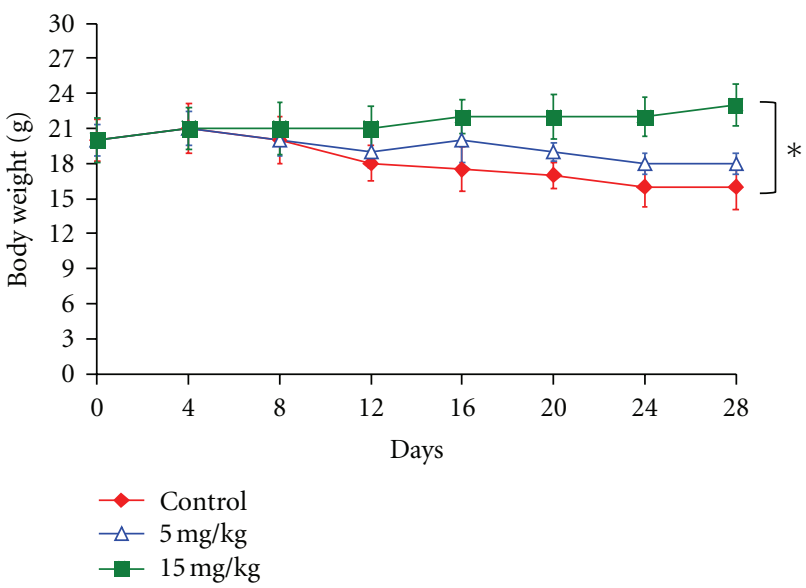

(d)

FIGURE 7: SLE inhibited tumor growth in the WEHI-3 cells allograft model. Eighteen BALB/c mice were subcutaneously implanted with $1 \times 10^{7}$ WEHI-3 cells. When tumors reached the volume of $100 \mathrm{~mm}^{3}$, the mice were randomly divided into three groups (six mice/group) Group 1 was orally treated with control vehicle (olive oil) daily; group 2 was orally treated with $5 \mathrm{mg} / \mathrm{kg}$ of SLE daily; group 3 was orally treated with $15 \mathrm{mg} / \mathrm{kg}$ of SLE daily. At day 28, all animals were sacrificed. Representative (a) animals with tumor, (b) tumor weight, (c) solid tumor volume, and $(\mathrm{d})$ body weight from each animal were shown. Data are presented as the mean \pm S.E.M. of six animals at day 0 to 28 after tumor implantation. ${ }^{*}, P<0.05$, significantly different compared with control.

p53 protein level which was associated with cell cycle arrest (Figure 6(a)) in WEHI-3 cells. The function of p53 plays an important role in inducing cell cycle checkpoints and apoptosis in human and murine cells following ROS-induced DNA damage [48]. Our results demonstrated that induction of p53 by SLE not only caused $G_{0} / G_{1}$ phase arrest but also triggered apoptosis in WEHI-3 cells. Pretreatment with PFT $\alpha$ in SLE-treated WEHI-3 cells restored the cell viability (Figure $4(\mathrm{~d})$ ), suggesting the functional involvement in p53-dependent pathway. To confirm this hypothesis, further investigations such as those using p53-specific siRNA are needed.

Apoptosis is important in normal cell homeostasis and apoptosis induction is one of the best strategies for cancer treatment $[4,49]$. Apoptotic signaling pathway can be divided into: (i) the death receptor includes Fas/FasL, tumor necrosis factor (TNF)/TNF receptors, and death receptor 4,5 $(\mathrm{DR} 4,5) / \mathrm{DR} 4,5$ receptors and their downstream molecules are caspases-8 $[4,6]$; (ii) the mitochondria-mediated pathway shows apoptotic stimuli induced by radiation, ROS production, and chemotherapy. Loss of $\Delta \Psi_{m}$ could cause cytochrome $c$, Apaf-1, procaspase- 9 releases and lead to the activation of the caspase cascade [4]. However, the cross-talk between these two apoptotic pathways also exists $[11,37,50$, 51]. In this study, we observed that SLE induced cell death with characteristics of apoptosis (Figure 3). Our data showed that the activities and protein levels of caspase-8, -9, and -3 were increased in SLE-treated WEHI- 3 cells in a timedependent manner (Figures 3-5). The extrinsic and intrinsic apoptotic pathways-associated proteins (Figure 6) were changed, which subsequently promoted caspase- 8 and caspase- 9 activation to activate downstream effectors caspase3 in SLE-treated WEHI-3 cells. Lee et al. reported that hexane fraction of Solanum lyratum herba induced apoptosis through activated caspase- $8,-9$, and -3 proteins in LLC cells [22]. The previous studies [18-20, 22] supported our 
suggestions to show that SLE induced apoptosis in WEHI-3 cells through both extrinsic- and intrinsic-dependent signaling pathways.

The present study also investigated diosgenin, a food saponin and one of the compounds isolated from SLE [15, 23, 52], whether affects murine leukemia WEHI-3 cells. Importantly, we also found that there are many similar results in diosgenin-treated WEHI-3 cells when compared with that in WEHI-3 cells after SLE exposure. Based on these findings, diosgenin-provoked apoptosis in WEHI-3 cells is involved in the p53-regulated both extrinsic and intrinsic signaling pathways. This report is agreed with other studies described by Bertrand et al. regarding diosgenin treatment that triggered subsequent extrinsic and intrinsic apoptotic signaling in human erythroleukemia (HEL) cells [52, 53]. Moreover, our data shown in Figure 2(b) is consistent with the previous research that diosgenin promoted $\mathrm{G}_{1} / \mathrm{G}_{0}$ phase arrest in primary human thyrocytes $[49,54]$. Intriguingly, Srinivasan et al. stated that diosgenin processed chemotherapeutic effects through targeting Akt-mediated NF- $\kappa \mathrm{B}$ and MAPK (prosurvival) signaling in human breast carcinoma (BCa) cells [49]. Hence, we suggest that SLE and diosgenin might be as potent anticancer agents for treating leukemia patients.

In summary, we demonstrated the molecular mechanisms underlying SLE-induced antitumor activity in WEHI3 murine leukemia cells in vitro and in vivo. SLE inhibited cell proliferation in WEHI-3 murine leukemia cells through $\mathrm{G}_{0} / \mathrm{G}_{1}$ phase arrest, extrinsic- and intrinsic-related pathways, which is involved in p53 activation. Understanding the manner of SLE-affected cell cycle progression and triggered apoptotic pathways will facilitate the development of treatment of leukemia in the future.

\section{Acknowledgments}

This investigation was supported by a research Grant from the National Science Council of the Republic of China (NSC 97-2320-B-039-004-MY3). This research was also supported by the Grants CMU96-086 and CMU96-087 from China Medical University and by a Grant DOH101-TD-C-111-005 from Taiwan Department of Health, China Medical University Hospital Cancer Research Center of Excellence.

\section{References}

[1] J. P. Lin, J. S. Yang, J. J. Lin et al., "Rutin inhibits human leukemia tumor growth in a murine xenograft model in vivo," Environmental Toxicology, vol. 13, no. 4, 2011.

[2] H. Sack, "Leukemia in patients with breast carcinoma after adjuvant chemotherapy and/or postoperative radiotherapy," Strahlentherapie Und Onkologie, vol. 171, no. 7, pp. 420-421, 1995.

[3] D. R. Green and J. C. Reed, "Mitochondria and apoptosis," Science, vol. 281, no. 5381, pp. 1309-1312, 1998.

[4] S. J. Riedl and G. S. Salvesen, "The apoptosome: signalling platform of cell death," Nature Reviews Molecular Cell Biology, vol. 8, no. 5, pp. 405-413, 2007.

[5] J. F. Kerr, A. H. Wyllie, and A. R. Currie, "Apoptosis: a basic biological phenomenon with wide-ranging implications in tissue kinetics," British Journal of Cancer, vol. 26, no. 4, pp. 239-257, 1972.

[6] K. M. Debatin, "Apoptosis pathways in cancer and cancer therapy," Cancer Immunology, Immunotherapy, vol. 53, no. 3, pp. 153-159, 2004.

[7] R. Zheng, Z. Zhang, X. Lv et al., "Polycystin-1 induced apoptosis and cell cycle arrest in g0/g1 phase in cancer cells," Cell Biology International, vol. 32, no. 4, pp. 427-435, 2008.

[8] H. Yano, A. Mizoguchi, K. Fukuda et al., "The herbal medicine sho-saiko-to inhibits proliferation of cancer cell lines by inducing apoptosis and arrest at the $\mathrm{G}_{0} / \mathrm{G}_{1}$ phase," Cancer Research, vol. 54, no. 2, pp. 448-454, 1994.

[9] J. Y. Liu, M. J. Lee, H. M. Chen et al., "Ocimum gratissimum aqueous extract protects h9c2 myocardiac cells from $\mathrm{H}_{2} \mathrm{O}_{2}-$ induced cell apoptosis through akt signalling," Evidence-Based Complementary and Alternative Medicine, vol. 2011, Article ID 578060, 8 pages, 2011.

[10] D. Robbins, X. Gu, R. Shi et al., "The chemopreventive effects of protandim: modulation of $\mathrm{p} 53$ mitochondrial translocation and apoptosis during skin carcinogenesis," Plos One, vol. 5, no. 7, Article ID e11902, 2010.

[11] G. Evan and T. Littlewood, "A matter of life and cell death," Science, vol. 281, no. 5381, pp. 1317-1322, 1998.

[12] W. Yalin, P. Yuanjiang, and S. Cuirong, "Isolation, purification and structural investigation of a water-soluble polysaccharide from Solanum lyratum thunb," International Journal of Biological Macromolecules, vol. 36, no. 4, pp. 241-245, 2005.

[13] B. Kang, E. Lee, I. Hong, J. Lee, and H. Kim, "Abolition of anaphylactic shock by Solanum lyratum thunb," International Journal of Immunopharmacology, vol. 19, no. 11-12, pp. 729734, 1998.

[14] J. S. Yang, C. C. Wu, C. L. Kuo et al., "Solannm lyratum extract affected immune response in normal and leukemia murine animal in vivo," Human and Experimental Toxicology, vol. 29, no. 5, pp. 359-367, 2010.

[15] L. X. Sun, W. W. Fu, W. Li, K. S. Bi, and M. W. Wang, "Diosgenin glucuronides from Solanum lyratum and their cytotoxicity against tumor cell lines," Zeitschrift Fur Naturforschung. C, vol. 61, no. 3-4, pp. 171-176, 2006.

[16] J. Ren, G. N. Feng, M. W. Wang, and L. X. Sun, "Primary study on the anti-tumor effect of ethanol extracts of Solanum lyratum," China Journal of Chinese Materia Medica, vol. 31, no. 6, pp. 497-500, 2006.

[17] L. X. Sun, W. W. Fu, J. Ren, L. Xu, K. S. Bi, and M. W. Wang, "Cytotoxic constituents from Solanum lyratum," Archives of Pharmacal Research, vol. 29, no. 2, pp. 135-139, 2006.

[18] X. Wei, C. G. Li, S. Nong, X. Y. Zhu, and X. M. Huang, "The influence of Solanum lyratum thunb extract on apoptosis and the expression of fas/fasl genes in hela cells," Zhong Yao Cai, vol. 29, no. 11, pp. 1203-1206, 2006.

[19] C. M. Shan and J. Li, "Study of apoptosis in human liver cancers," World Journal of Gastroenterology, vol. 8, no. 2, pp. 247-252, 2002.

[20] S. Q. Gu, Y. Y. Liang, L. R. Fan et al., "Co-regulative effects of the cAMP/PKA and DAG/PKC signal pathways on human gastric cancer cells during differentiation induced by traditional Chinese medicines," World Journal of Gastroenterology, vol. 3, no. 1, pp. 50-53, 1997.

[21] S. C. Hsu, J. H. Lu, C. L. Kuo et al., "Crude extracts of Solanum lyratum induced cytotoxicity and apoptosis in a human colon adenocarcinoma cell line (colo 205)," Anticancer Research, vol. 28, no. 2 A, pp. 1045-1054, 2008.

[22] J. H. Lee, Y. H. Lee, H. J. Lee et al., "Caspase and mitogen activated protein kinase pathways are involved in Solanum lyratum 
herba induced apoptosis," Journal of Ethnopharmacology, vol. 123, no. 1, pp. 121-127, 2009.

[23] L. Yang, F. Feng, and Y. Gao, "Chemical constituents from herb of Solanum lyratum," Zhongguo Zhongyao Zazhi, vol. 34, no. 14, pp. 1805-1808, 2009.

[24] R. M. Zucker, K. H. Elstein, R. E. Easterling, and E. J. Massaro, "Flow cytometric comparison of the effects of trialkyltins on the murine erythroleukemic cell," Toxicology, vol. 58, no. 2, pp. 107-119, 1989.

[25] C. C. Lu, J. S. Yang, A. C. Huang et al., "Chrysophanol induces necrosis through the production of ros and alteration of atp levels in j5 human liver cancer cells," Molecular Nutrition and Food Research, vol. 54, no. 7, pp. 967-976, 2010.

[26] J. H. Chiang, J. S. Yang, C. Y. Ma et al., "Danthron, an anthraquinone derivative, induces dna damage and caspase cascades-mediated apoptosis in snu-1 human gastric cancer cells through mitochondrial permeability transition pores and bax-triggered pathways," Chemical Research in Toxicology, vol. 24, no. 1, pp. 20-29, 2011.

[27] I. Nicoletti, G. Migliorati, M. C. Pagliacci, F. Grignani, and C. Riccardi, "A rapid and simple method for measuring thymocyte apoptosis by propidium iodide staining and flow cytometry," Journal of Immunological Methods, vol. 139, no. 2, pp. 271-279, 1991.

[28] S. H. Wu, L. W. Hang, J. S. Yang et al., "Curcumin induces apoptosis in human non-small cell lung cancer nci-h460 cells through er stress and caspase cascade- and mitochondria-dependent pathways," Anticancer Research, vol. 30, no. 6, pp. 2125-2133, 2010.

[29] J. G. Chung, J. S. Yang, L. J. Huang et al., "Proteomic approach to studying the cytotoxicity of yc-1 on u937 leukemia cells and antileukemia activity in orthotopic model of leukemia mice," Proteomics, vol. 7, no. 18, pp. 3305-3317, 2007.

[30] M. Kobara, N. Sunagawa, M. Abe et al., "Apoptotic myocytes generate monocyte chemoattractant protein-1 and mediate macrophage recruitment," Journal of Applied Physiology, vol. 104, no. 3, pp. 601-609, 2008.

[31] W. W. Huang, J. S. Yang, C. F. Lin, W. J. Ho, and M. R. Lee, "Pycnogenol induces differentiation and apoptosis in human promyeloid leukemia hl-60 cells," Leukemia Research, vol. 29, no. 6, pp. 685-692, 2005.

[32] X. Chen, P. Lv, J. Liu, and K. Xu, "Apoptosis of human hepatocellular carcinoma cell (hepg2) induced by cardiotoxin iii through s-phase arrest," Experimental and Toxicologic Pathology, vol. 61, no. 4, pp. 307-315, 2009.

[33] M. Müller, S. Strand, H. Hug et al., "Drug-induced apoptosis in hepatoma cells is mediated by the cd95 (APO- 1/FAS) receptor/ligand system and involves activation of wild-type p53," Journal of Clinical Investigation, vol. 99, no. 3, pp. 403-413, 1997.

[34] J. A. Houghton, F. G. Harwood, and D. M. Tillman, “Thymineless death in colon carcinoma cells is mediated via fas signaling," Proceedings of the National Academy of Sciences of the United States of America, vol. 94, no. 15, pp. 8144-8149, 1997.

[35] Y. C. Li, H. J. Lin, J. H. Yang et al., "Baicalein-induced apoptosis via endoplasmic reticulum stress through elevations of reactive oxygen species and mitochondria dependent pathway in mouse-rat hybrid retina ganglion cells (n18)," Neurochemical Research, vol. 34, no. 3, pp. 418-429, 2009.

[36] F. S. Yu, J. S. Yang, C. S. Yu et al., "Safrole induces apoptosis in human oral cancer hsc-3 cells," Journal of Dental Research, vol. 90, no. 2, pp. 168-174, 2011.

[37] J. S. Yang, G. W. Chen, T. C. Hsia et al., "Diallyl disulfide induces apoptosis in human colon cancer cell line (colo 205) through the induction of reactive oxygen species, endoplasmic reticulum stress, caspases casade and mitochondrial-dependent pathways," Food and Chemical Toxicology, vol. 47, no. 1, pp. 171-179, 2009.

[38] T. Dai, H. Zheng, and G. S. Fu, "Full-length article hypoxia confers protection against apoptosis via the pi3k/akt pathway in endothelial progenitor cells," Acta Pharmacologica Sinica, vol. 29, no. 12, pp. 1425-1431, 2008.

[39] J. S. Yang, M. J. Hour, W. W. Huang, K. L. Lin, S. C. Kuo, and J. G. Chung, "Mj-29 inhibits tubulin polymerization, induces mitotic arrest, and triggers apoptosis via cyclin-dependent kinase 1-mediated bcl-2 phosphorylation in human leukemia u937 cells," Journal of Pharmacology and Experimental Therapeutics, vol. 334, no. 2, pp. 477-488, 2010.

[40] P. P. Wu, K. C. Liu, W. W. Huang et al., "Diallyl trisulfide (dats) inhibits mouse colon tumor in mouse ct-26 cells allograft model in vivo," Phytomedicine, vol. 18, no. 8-9, pp. 672-676, 2011.

[41] L. C. Chou, J. S. Yang, L. J. Huang et al., “The synthesized 2-(2fluorophenyl)-6,7-methylenedioxyquinolin-4-one (chm-1) promoted $\mathrm{g} 2 / \mathrm{m}$ arrest through inhibition of cdk 1 and induced apoptosis through the mitochondrial-dependent pathway in ct-26 murine colorectal adenocarcinoma cells," Journal of Gastroenterology, vol. 44, no. 10, pp. 1055-1063, 2009.

[42] D. Dilloo, M. Brown, M. Roskrow et al., "Cd40 ligand induces an antileukemia immune response in vivo," Blood, vol. 90, no. 5, pp. 1927-1933, 1997.

[43] S. Haupt, M. Berger, Z. Goldberg, and Y. Haupt, "Apoptosisthe p53 network," Journal of Cell Science, vol. 116, no. 20, pp. 4077-4085, 2003.

[44] S. Bates and K. H. Vousden, "Mechanisms of p53-mediated apoptosis," Cellular and Molecular Life Sciences, vol. 55, no. 1, pp. 28-37, 1999.

[45] N. A. Liu, H. Jiang, A. Ben-Shlomo et al., "Targeting zebrafish and murine pituitary corticotroph tumors with a cyclin-dependent kinase (cdk) inhibitor," Proceedings of the National Academy of Sciences of the United States of America, vol. 108, no. 20, pp. 8414-8419, 2011.

[46] M. Mihara, S. Shintani, K. I. Nakashiro, and H. Hamakawa, "Flavopiridol, a cyclin dependent kinase (cdk) inhibitor, induces apoptosis by regulating bcl-x in oral cancer cells," Oral Oncology, vol. 39, no. 1, pp. 49-55, 2003.

[47] T. Hunter and J. Pines, "Cyclins and cancer ii: cyclin d and cdk inhibitors come of age," Cell, vol. 79, no. 4, pp. 573-582, 1994.

[48] P. May and E. May, "Twenty years of p53 research: structural and functional aspects of the p53 protein," Oncogene, vol. 18, no. 53, pp. 7621-7636, 1999.

[49] S. Srinivasan, S. Koduru, R. Kumar, G. Venguswamy, N. Kyprianou, and C. Damodaran, "Diosgenin targets akt-mediated prosurvival signaling in human breast cancer cells," International Journal of Cancer, vol. 125, no. 4, pp. 961-967, 2009.

[50] G. M. Cohen, "Caspases: the executioners of apoptosis," Biochemical Journal, vol. 326, no. 1, pp. 1-16, 1997.

[51] J. C. Chen, K. W. Lu, M. L. Tsai et al., "Gypenosides induced $\mathrm{g} 0 / \mathrm{g} 1$ arrest via chk2 and apoptosis through endoplasmic reticulum stress and mitochondria-dependent pathways in human tongue cancer scc-4 cells," Oral Oncology, vol. 45, no. 3, pp. 273-283, 2009.

[52] J. Raju and R. Mehta, "Cancer chemopreventive and therapeutic effects of diosgenin, a food saponin," Nutrition and Cancer, vol. 61, no. 1, pp. 27-35, 2009. 
[53] C. Cailleteau, B. Liagre, and J. L. Beneytout, "A proteomic approach to the identification of molecular targets in subsequent apoptosis of hel cells after diosgenin-induced megakaryocytic differentiation," Journal of Cellular Biochemistry, vol. 107, no. 4, pp. 785-796, 2009.

[54] D. Bian, Z. Li, H. Ma et al., "Effects of diosgenin on cell proliferation induced by igf-1 in primary human thyrocytes," Archives of Pharmacal Research, vol. 34, no. 6, pp. 997-1005, 2011. 


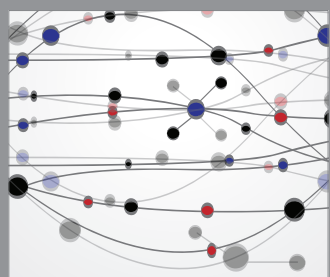

The Scientific World Journal
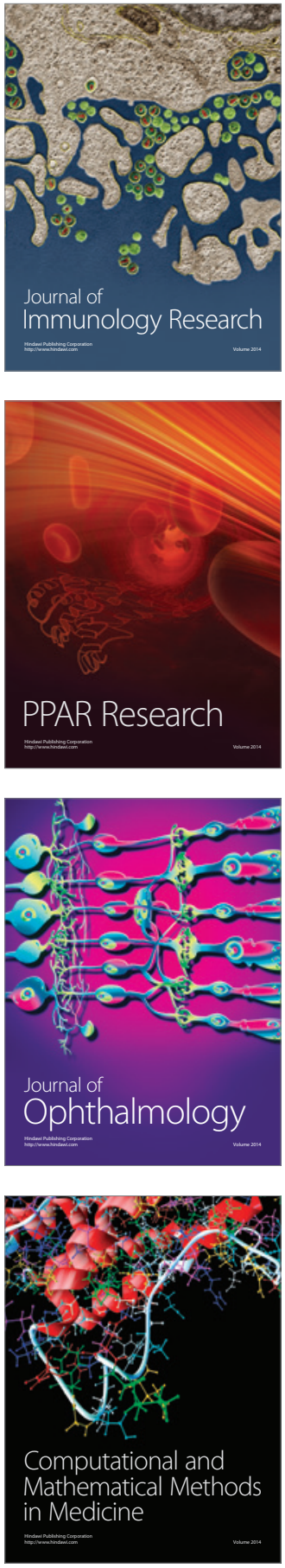

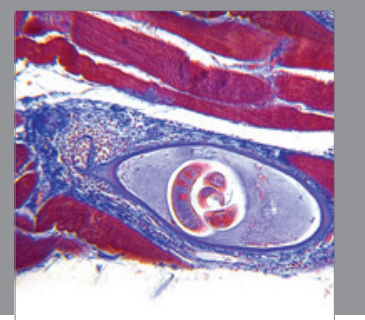

Gastroenterology

Research and Practice
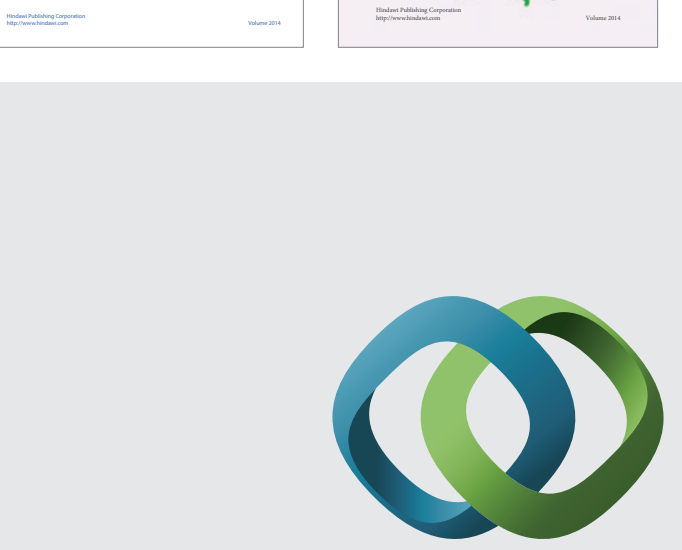

\section{Hindawi}

Submit your manuscripts at

http://www.hindawi.com
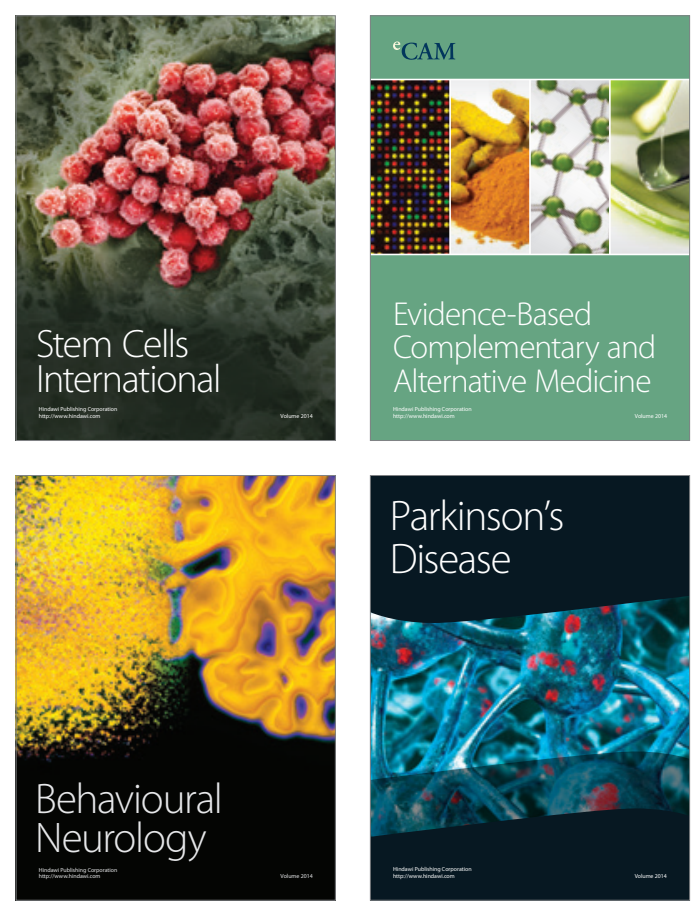

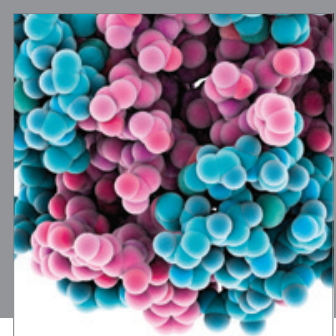

Journal of
Diabetes Research

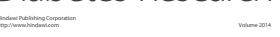

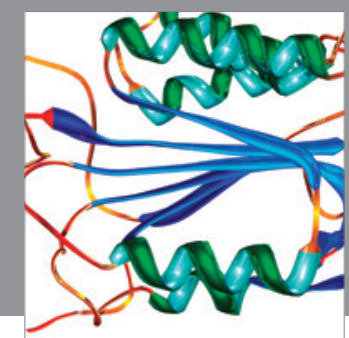

Disease Markers
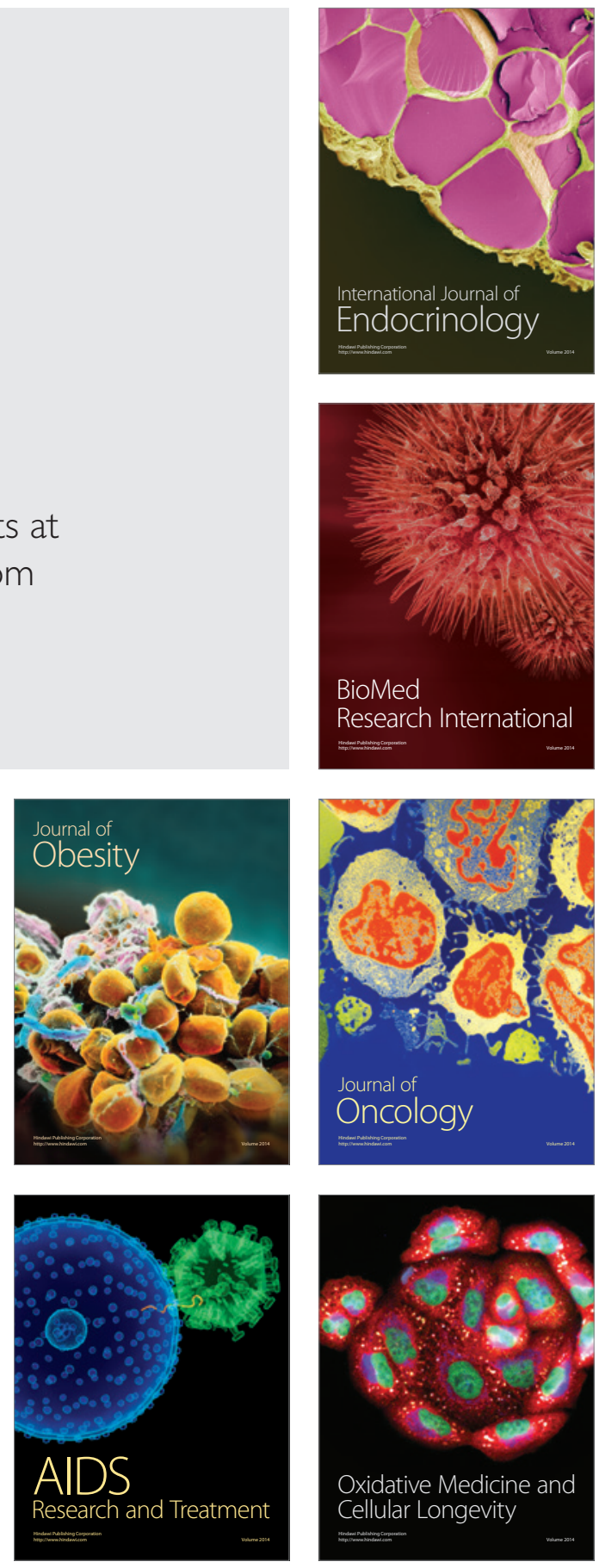